\title{
Leaving Home, Moving to College, Returning Home: Economic Outcomes in the United States
}

\author{
Maria Sironi \\ Corresponding Author: Department of Social Science, University College London, \\ 55-59 Gordon Square, Bloomsbury, London WC1H ONU \\ m.sironi@ucl.ac.uk \\ +44(0) 2079115503
}

\begin{abstract}
Francesco C. Billari
Department of Policy Analysis and Public Management and Carlo F. Dondena Centre for Social Dynamics and Public Policy, Bocconi University

francesco.billari@unibocconi.it
\end{abstract}

\begin{abstract}
Leaving the parental home is a milestone in the transition to adulthood. Historical changes in leaving home have been well documented in the literature. However, research investigating the consequences associated with the timing and pathway of leaving (and returning) home is still scant. Building mainly on capital accumulation and life course theories, we analyze data from the National Longitudinal Survey of Youth (NLSY97) on young Americans born between 1980 and 1984, who are 27-31 years old in 2011. We find an M-shaped relationship between age at leaving home and working and economic conditions later on: leaving 'too early', 'too late' or at nonnormative ages is negatively associated with labor market outcomes. Also, among those who have been enrolled in college, leaving home to go to college, during college, or after college is positively associated with subsequent income, compared to leaving before college. Moving back in with parents is negatively associated with economic outcomes.
\end{abstract}

Keywords: Transition to Adulthood; Leaving Home; Employment Status; Income; Returning Home.

\section{Conflict of Interest Declaration}

The authors declare not to have any conflict of interest. 


\section{Introduction}

Among the most noticeable changes in the life course during the last century are those in the transition to adulthood (Modell, Furstenberg, \& Hershberg, 1976), which is considered a 'demographically dense' period (Rindfuss, 1991) that crucially shapes the subsequent life course trajectory. During the last decades, the economic circumstances of young people have progressively deteriorated in relative terms, as signaled, for instance, by the ability to achieve economic independence at later ages for more recent cohorts (Sironi \& Furstenberg, 2012). It is therefore crucial to investigate the relationship between the transition to adulthood and subsequent economic circumstances: this is our main focus.

The age at leaving the parental home, a key marker of independence, has significantly increased in many Western societies (Aassve, Billari, Mazzucco, \& Ongaro, 2002; Billari, 2004; Cherlin, Scabini, \& Rossi, 1997; Mandic, 2008). Still, there are relevant cross-national differences (Billari \& Liefbroer, 2010; Buchmann \& Kriesi, 2011), and some have linked these differences to differences in macro-economic performance, with the idea inspired by Southern Europe that late home leaving has a general negative effect on the economy as it can deteriorate the accumulation of human (and social) capital of young adults (Alesina \& Giuliano, 2007; Alessie, Brugiavini, \& Weber, 2005; Billari \& Tabellini, 2011). In the United States, the postponement of leaving the parental home has been less pronounced, mainly due to the growing fraction of teenagers who move out to go to college. However, the median age at leaving home has not remained constant over time, and the occurrence of young adults returning to live with their parents after a temporary independence has become more and more prevalent (Da Vanzo \& Goldscheider, 1990; Goldscheider \& Goldscheider, 1994; Qian, 2012; South \& Lei, 2015). Moreover, the living arrangements of young adults have been sensitive to cyclical economic conditions and to the 
relative level of youth wages (Card \& Lemieux, 2000). Living arrangements decisions during the transition to adulthood are driven by many different factors, in addition to economic circumstances. Social norms play an important role in life course decisions, and in particular during the transition to adulthood. Social norms on the age (timing) and reasons (destinations) for leaving home, as well as on returning to the parental home can influence these decisions (Billari \& Liefbroer, 2007; Liefbroer \& Billari, 2010; Settersten, 1998; Settersten \& Hagestad, 1996).

While the determinants of home-leaving have been extensively studied in the literature (South \& Lei, 2015), the consequences of becoming, and remaining, independent have not been given adequate attention so far. Specifically, the 'legacy' (Leopold, 2012) of leaving and returning home has been investigated mainly with an emphasis on family outcomes and relationships (Billari \& Rosina, 2004; Goldscheider \& Waite, 1987; Leopold, 2012; Mulder \& Clark, 2002; Waite, KobrinGoldscheider, \& Witsberger, 1986) or education (White \& Lacy, 1997). Three papers are partial exceptions to this gap in the literature on the economic consequences of leaving and returning home. First, Halleröd and Westberg (2006) investigate the effects of home-leaving on income trajectories and deprivation in Sweden, a society characterized by a strong welfare support (Esping-Andersen, 1999). Halleröd and Westberg find an initial negative effect of early homeleaving, which is counter-balanced at later ages by faster income growth and lower deprivation rates. Second, Parisi (2008) studies the effect of leaving home on poverty in Southern European countries, and finds that young adults who delay leaving home are less likely to enter poverty when they actually leave. Third, Ribar (2015) finds similar results for Australia, showing higher poverty rates for young adults right after they leave the parental home and concluding that, in general, "leaving home is a hardship". 
This paper tackles the gap in the literature by analyzing U.S. longitudinal data. In particular, we study how employment and economic conditions in the early thirties are affected by the age at leaving home, whether leaving home is connected to college attendance, and whether young adults return home. We use the National Longitudinal Survey of Youth 1997 (NLSY97) to study men and women in the United States born between 1980 and 1984. We exploit information in the NLSY about living arrangements in order to study outcomes like income from work and working conditions, such as employment status, job tenure, and hours worked per week when youth are in their late twenties and early thirties. This kind of information, especially on employment history, is quite rare in mobility studies on young adults. We also take into account the socio-demographic characteristics of the respondents, their family background, and their educational attainment.

The remainder of this paper is organized as follows: The next section introduces our background and hypotheses. Section 3 illustrates the data and methods we use. Section 4 contains the descriptive findings and results from multivariate analyses. Section 5 concludes with a discussion and implications for policy and research.

\section{Background and Hypotheses}

What are the economic consequences of the timing and pathways of home leaving, and of returning home? We now review and build on some of the ideas from the literature, and derive some guiding hypotheses for our subsequent empirical analyses.

Our theoretical background develops two strands of literature. First, we build on the mainly economic literature focusing on human (and social) capital accumulation, considering capital 
accumulation as the main building block of economic circumstances in early adulthood. For what concerns the timing of home-leaving, effects on capital accumulation might be ambiguous. On the one hand, residential autonomy per se might foster skills that are not acquired when living with parents, such as organizational and practical skills, or more general "non-cognitive" skills (Heckman \& Rubinstein, 2001) that might be valued in the labor market — such as a "taste for independence" (Goldscheider \& Waite, 1987; Mulder \& Clark, 2002; Waite et al., 1986). Therefore, this would predict a negative effect of staying longer with parents, where leaving home later will carry a penalty. Billari and Tabellini (2008) document a case of late home-leaving penalty, using the rather extreme Italian case: they estimate that one additional year of delay in leaving home corresponds to the loss of about a third of a year of education. On the other hand, the protective environment of the parental home might be useful to focus on obtaining specific skills that are valued on the labor market, such as any kind of education, which could help in fostering, through one's own parents and the local community, the "weak ties" that matter for labor market outcomes (Granovetter, 1973) and therefore social capital. A longer co-residence might prevent young adults from falling into unemployment and/or poverty (Aassve, Davia, Iacovou, \& Mazzuco, 2007; Parisi, 2008). If spells of unemployment and poverty have effects that persist, i.e. "scarring" effects (Gangl, 2004, 2006), then a longer co-residence with parents will become protective in the long run, and there will be a later leaving home prize. In terms of human (and social) capital accumulation, the direction of the effects of the age at leaving home on the labor market outcomes is ambiguous, i.e. it is not clear whether the penalty or the prize argument prevail. However, when leaving the parental home is directly associated with the acquisition of human capital, as in the case of leaving home to attend higher education, the "late home leaving penalty" argument becomes weaker. The loss of ties with the young adult's community (and therefore of 
social capital) might still be relevant, but it might be compensated by moves to areas that tend to have above average labor markets. Whether young adults leave home to attend college or not might also be linked to later outcomes. Young adults who have moved to study tend to earn more later in life (Kidd, O'Leary, \& Sloane, 2017). For what concerns capital accumulation, returning home might have a function of protecting young adults through embedding them in the social networks of their family's place of origin, therefore acting as insurance against labor market riskstherefore, potentially having a positive effect on later economic outcomes (Kaplan, 2012). Returning home might also let "boomerang" children fall back in terms of independence and therefore have a negative effect on later economic outcomes. There might also be potential longterm consequences of the short-term effects of leaving home (Parisi, 2008; Ribar, 2015). If leaving home is a hardship, with negative economic consequences, these negative consequences could carry over to later ages, remaining stable if not accumulating over the course of time, similarly to the "scarring" effects of unemployment (Gangl, 2004, 2006). Nevertheless, the analysis on Sweden by Halleröd and Westberg (2006) shows that the economically adverse consequences of early home-leaving decrease over time. As we shall see, reverse causality is hard to tackle in particular for what concerns returning home, given that young adults can decide to move back home if their economic conditions deteriorate.

The second strand of literature we build upon is the life course approach (Elder, 1975; Settersten \& Mayer, 1997), and in particular the idea that life course trajectories are shaped by normative constraints and guidelines. In accordance with the literature, we hypothesize that social norms exist on the timing and pathway of leaving (and returning) home (Liefbroer \& Billari, 2010). The life course literature mentions social norms as underlying variations in the trajectories of young 
adults' living arrangements between (Billari, Philipov, \& Baizán, 2001; Buchmann \& Kriesi, 2011; Iacovou, 2002) and within countries (Aassve, Arpino, \& Billari, 2013; Holdsworth, 1998). For the U.S., pioneering studies by Settersten and Hagestad (Settersten, 1998; Settersten \& Hagestad, 1996) on a small sample of respondents in the Chicago Metropolitan Area showed that there was almost universal consensus that young men and women should leave home between the ages of 18 and 25, with a modal age deadline for leaving home of 18 for women and 21 for men. Reasons mentioned in the Chicago Metropolitan Area study were mainly related to the development of self and personality, i.e. related to the acquisition of human capital that we have previously discussed. Later research has documented the relevance of age norms in shaping young adults home-leaving decisions (Billari \& Liefbroer, 2007). In a study based on the 2002 General Social Survey, $82 \%$ of Americans answered that they considered leaving home being at least "somewhat important" to being considered an adult (in contrast with 52\% for having a child and 55\% for getting married) (Furstenberg, Kennedy, McLoyd, Rumbaut, \& Settersten, 2004). Hence, leaving home at normative ages - such as 18 years old to go to college, or 21-22 at the end of college - might be associated with positive outcomes. Moreover, and specifically concerning the U.S., scholars have emphasized the relevance of the individualistic culture and the college system that encourages students to live on campus and to relocate (Avery, Goldscheider, \& Speare, 1992; Buchmann, 1989; Goldscheider \& Goldscheider, 1993, 1994; Goldscheider \& Goldscheider, 1998; Mulder \& Clark, 2000; Mulder, Clark, \& Wagner, 2002).

Based on this theoretical background, our first and general hypothesis is that the positive effects of co-residence with parents prevail at younger ages at leaving home and the negative effects prevail at older ages for what concerns capital accumulation and economic outcomes. Leaving at 
ages that are normatively "too early" or "too late" might carry a penalty. Therefore, we predict an inverse U-shaped association between age of home-leaving and labor market outcomes:

H1: The association between the age at leaving home and economic outcomes is inversely $U$ shaped, i.e. there is a penalty for leaving home "too early" and for leaving home "too late" in terms of later labor market outcomes

For what concerns the pathway out of the parental home, we focus on whether leaving home is linked to pursuing education. Using data from the 1986-87 National Survey on Families and Households, White and Lacy have shown that young people who leave the parental home to attend college have higher educational attainment (White \& Lacy, 1997). The key question is whether leaving home to pursue education has an effect over and above educational achievement, i.e. for instance, among those who attend college as well. If we apply the same reasoning as before, for youth enrolled in college, the "positive" aspects of residential independence, or more properly in this case, semi-autonomy (Goldscheider \& DaVanzo, 1986) will prevail, fostering non-cognitive skills that are valued in the labor market, while the negative aspects are buffered by college enrolment. In addition, leaving home to attend college is, in the U.S., a normative way to leave home. Therefore, our second hypothesis is:

H2: Among young adults who attend college, leaving home to attend college or during college as opposed to leaving home before or after college - is associated with a prize in terms of later labor market outcomes

We now turn to the consequences of returning to the parental home. In the early, pioneering, study of Settersten, age norms were not seen as constraining the decision to return to the parental home 
(Settersten, 1998). Respondents saw the decision to return to the parental home as regarding needs and circumstances. For the U.S., Mulder and Clark (2002) find evidence that the likelihood of returning home increases with parental income, and South and Lei (2015) find that graduating from college or dissolving a partnership precipitates moving back to the parental home. For the U.K., Stone et al. (2014) find that the likelihood of returning home increases in general with "turning points" in the life course, such as leaving full-time education, unemployment, or partnership dissolution. Returning home is, therefore, a response to difficult circumstances, and the effect of these circumstances might still be visible in later life. Here, causality is the trickiest, as it is likely that young adults who anticipate worse economic outcomes later in life are more frequently returning home. However, a negative association is consistently predicted in accordance with the literature. Therefore, our third hypothesis is:

H3: Returning to the parental home carries a "penalty", i.e. it is associated with negative later labor market outcomes

\section{Data and Methods}

Our analysis investigates the association between the age at leaving home of young Americans born between 1980 and 1984 and economic and employment outcomes in 2010/2011. The analysis has been carried out using the National Survey of Youth started in 1997. The NLSY97 is an ongoing, nationally representative longitudinal study of 8,984 youths who were 12 to 16 years old in 1997. The first round took place in 1997 and respondents are interviewed and followed on an annual basis. We use the fifteenth wave that has been collected in 2011 , and includes 7,423 individuals between 27 and 31 years old. Two new waves were collected in 2013 and 2015. However, since we need information yearly, we decided to stop our analysis to 2011. The data set 
has been created to document the transition from school to work and from adolescence to adulthood. Hence, the NLSY collects detailed information on educational trajectories and labor market experiences of the respondents. In particular, it includes specific information on employment histories and weekly working hours, which has seldomly been used in studies on the living arrangements of young adults. Also, it includes questions on family socioeconomic background, living arrangements and other demographic characteristics. Thus, it is possible to reconstruct life course trajectories from adolescence to the early thirties. The survey oversamples the black and Hispanic populations. For this reason, all descriptive statistics have been weighted using sampling weights.

\section{Dependent Variables}

As the main objective of the paper is to study the association between leaving (and returning) home and the economic and work conditions among young adults, our dependent variables aim at describing these conditions in our sample. We exploit the richness of the NLSY data and we firstly study whether respondents work full-time in 2011. Working full-time is defined as being employed (or self-employed) and working at least 35 hours per week. Second, to have a more detailed picture of respondents' employment situation, we also study the number of hours they work per week and the length of job tenure (i.e. for how many weeks respondents have had the same job). Job tenure is an indicator of (in)stability, which can be more informative than employment status per se, especially during times of economic recessions and high turnover (Hollister \& Smith, 2014). Finally, we explore income from work. Respondents are asked to state the income from wages and salary - before deductions for taxes - from all jobs received in the year preceding the interview (2010 in this case). They are also asked to report any income they received from self-employment, 
e.g. from own farm, business, etc. If a person is not employed, then the number of hours worked per week, job tenure, and income is set equal to zero. Further analyses have been conducted as robustness checks: excluding respondents with zero income or excluding those who are unemployed, the results of our analyses are consistent with those shown here.

\section{Independent Variables}

The NLSY97 contains a very relevant question that allows us to determine the exact age at which respondents left the parental home and to test our first hypothesis (H1): "What month and year did you first move out on your own for at least three months, even if you moved back in to someone else's household after that?". However, this question has been asked only from 2003 onwards. For those who did not answer, we resorted to using household roster information. Household rosters refer to the day of the interview, giving us only a partial picture of young adults' living arrangements. Additionally, not all respondents are interviewed every year, but they are reincluded in the sample when possible in the following waves. Based on this question on moving out, and on the household roster, we were able to collect information on the age at leaving home for 6,931 out of 7,423 individuals. Among them, 378 have never left the parental home as of 2011 wave. After excluding those who never left (378) and those with missing information on our dependent and control variables (1,037), our final subsample includes 5,582 individuals $(2,864$ women and 2,718 men), who in 2011 are on average 28.8 years old.

In order to test our second hypothesis (H2), we use extremely detailed monthly information on respondents being enrolled in college. In fact, it is possible to determine the first and the last months in which respondents have ever been enrolled in college, and, thus, several possible pathways of leaving home. It is important to notice that pathways of leaving home that are 
education-related can only be studied for those who have ever been enrolled in college. The pathways we look at are the following: a) leaving the parental home before going to college; b) leaving the parental home to go to college, i.e. during the three months preceding or following the month of the first enrolment in college; c) leaving the parental home during college, and finally, d) leaving the parental home only after leaving college (because of drop out or graduation).

Finally, the respondents of the NLSY97 are asked (also from 2003 onwards): "Did you ever move back in with your parents or into someone else's household for at least three months after that?" This data is complemented by the household grid, which gives information on whether, after a wave in which the respondent does not report living with parents, he/she subsequently reports parents as household members. Exploiting this information, we can study returning home, and we can test our third hypothesis (H3).

\section{Control Variables}

In order to control for socio-demographic characteristics of the respondents and of his/her family that could influence both leaving and returning home, and economic and employment outcomes, we include in the analysis gender ( $=0$ if male, $=1$ if female), self-reported health at the first interview in 1997 (ranging from 1=Excellent to 5=Poor), ethnicity (White, Hispanic, Black, and other ethnicity), and age at interview (because the age range in 2011 goes from 27 to 31, and it could be responsible for some fluctuations in income and employment status).

We also include measures relative to the parental family background and childhood health, which are normally used in studies of the determinants of leaving and returning home. As is well known in the literature, family background and early life conditions are important determinants of the transition to adulthood and of young adults' economic outcomes. Here, we use parents' education, 
as the highest grade completed by the biological father, or of the biological mother if higher. When information about biological (and residential) parents is not present, we used education of the residential (and non-biological) parents. Also, we used a variable measuring living arrangements before age 14, i.e. if the respondent lived with both biological parents until age 14 . We included the number of siblings, given that according to the 'resource dilution hypothesis', having more siblings means receiving less parental resources (Downey, D. B. 2001) that could be related to the decision of leaving home and also to labor market outcomes. We also included household income in 1997 (measured in quintiles) and a dichotomous variable expressing whether the respondent has ever lived through hard times in childhood. Finally, we used two variables related to the respondents' health in childhood (as measured in 1997): whether the respondent has a chronic condition and whether the respondent has problems that limit school or work (physical, emotional, or learning problems) $)^{1}$.

\section{Analytical strategy}

After producing some descriptive statistics that describe the sample characteristics and the distribution of the age at leaving the parental home, the pathways out of the parental home, and the probability of moving back, we move to a more direct discussion of our main hypotheses.

To test our first hypothesis (H1), i.e. that leaving the parental home 'too early', 'too late' or at non normative ages is associated with worse economic and employment outcomes later in life, we document graphically the association between the age at moving out and income from work, employment status, hours worked per week, and job tenure. The variation observed in the graphs

\footnotetext{
${ }^{1}$ As a control variable we also tried to include region of residence in 1997 (first year of the survey, when the individuals in the sample were between 12 and 16 years old). We also tried a combination of region of residence in 1997 and urban/rural residence. None of these variables were significant nor they changed the results in our analysis. We suspect that this might be due to the very large area that a region includes, i.e. Northeast, Northcentral, South and West.
} 
is then tested using multivariate regression models. Given the different nature of our key dependent variables, we implement two different model specifications: a logistic regression to look at employments status ( $=1$ if working full-time, $=0$ otherwise), and standard OLS regressions for the other three outcomes. In order to study the role of the age at leaving home in shaping young adults' economic outcomes, we introduce the key variables step by step. The first model includes only age at leaving home as a categorical variable (i.e. $\leq 17,18,19-20,21-22, \geq 23$ ) and the exogenous variables of gender, ethnicity, and age at interview. In the second model, we include family background and early life health variables as controls.

We then move to our second hypothesis (H2), analyzing the pathways of leaving home, and we split the sample between those who have never been enrolled in college and those who have been enrolled at least once. Looking only at the subsample of those who went to college, we introduce different pathways of leaving home. The first and the second models are the same as described above. We then include the pathways 'leaving to go to college', 'leaving during college', and 'leaving after leaving college', keeping 'leaving before college' as a reference category. Given the strong influence of educational attainment - and not only of enrollment - on labor market outcomes, in the last model we introduce a variable that is equal to 1 if the respondent attained a college degree and 0 otherwise.

Finally, to assess our third hypothesis (H3) about the role of moving back in with parents, we look at both subsamples ('never went to college' vs. 'have been enrolled in college'): For the subsample of those who never went to college, we run the same analysis as for the full sample and add a third model that introduces the variable ever moved back in with parents. For the subsample of those who attended college, on top of the analysis already performed to test $\mathrm{H} 2$, we add a specification that includes a variable on whether the individual has ever moved back in with parents. 
As robustness checks (and given possible differences in the age at leaving home among men and women), we replicated the analysis separately by gender and we also added models including an interaction between gender and ethnicity. The results ${ }^{2}$ are reported in the Appendix.

\section{Results}

\section{Descriptive Statistics}

Table 1 shows a first description of our sample. Given that only 5,582 young adults in our sample left the parental home at least once, we focus on this subsample. On average, young adults born between 1980 and 1984 have completed 14 years of education, 70.4\% of them have enrolled in college, and $43.6 \%$ got a college degree. The parents' average number of years of education is 13.8. Average age at leaving the parental home is 20.1 years, and of those who moved out of the parental home at least once, $42.1 \%$ moved back in for a period of at least three months. $53.1 \%$ lived with the biological parents until age 14 , and the average number of siblings is $2.5 .5 .2 \%$ of respondents experienced "hard times" during childhood. In 1997, 11.2\% reported having a chronic condition and $14.1 \%$ reported having a problem limiting school or work. In $2011,61.6 \%$ are working full-time. If active on the labor market, these young adults, on average, work 40.4 hours per week, have earned $\$ 35,893$ in 2010 , and have had the current job for three years and 11.5 months.

\section{[TABLE 1 ABOUT HERE]}

While Table 1 gives us a general picture of our sample, we aim to know in more detail at which age young adults leave their family of origin and how this is interconnected with economic

\footnotetext{
${ }^{2}$ These additional analyses show that the interaction between gender and ethnicity does not affect the main results. There are two main differences by gender: the association between age at leaving home and economic outcomes is M-shaped for women, while it is inverted U-shaped for men, and moving back to the parental home is not associated with a penalty among women.
} 
outcomes in their late twenties/early thirties. As can be seen from Figure 1, leaving home happens mostly between age 17 and 24 , with a median age of $19.5 .26 .8 \%$ leaves at age 18 , which usually corresponds to the beginning of college.

\section{[FIGURE 1 ABOUT HERE]}

As far as the pathways of home leaving are concerned, it is interesting to notice the heterogeneity in young adults' trajectories, and how these are also related to the possibility of returning to live with parents. In Table 2, we show the proportion of individuals who left the parental home a) before going to college; b) to go to college; c) during college, and d) after leaving college. Looking at the entire sample (both those who went to college and those who did not), 16.7\% leave home before going to college, while $20.5 \%$ move out of the parental home to go to college. Only $11 \%$ leave home during college, while the modal group is the one of young adults who go to college but stay with parents and leave home only after leaving college (22.3\%). These patterns of home leaving are interestingly related to the patterns of moving back in with parents. Among those who leave home before enrolling in college, $47.5 \%$ move back home for at least three months after leaving. This percentage is highest $-55.3 \%$ - among those who leave home to go to college, and lowest $-28.2 \%$ - for respondents who leave home after college. This last result is likely due to the fact that students who stay with parents during college are older when they decide to move out. The high proportion of young adults who move back in with parents among those who leave for the first time in order to go to college is less straightforward. Possibly these respondents would not have left so early had they not gone to college, so they decide to move back in with parents. Alternatively, it could be that at the end of college they couldn't get a job offer and decide to move back home until they find employment. What is relevant is that quite a lot of heterogeneity exists 
in when and why people decide to leave the parental home, which is connected to the subsequent probability of moving back.

\section{[TABLE 2 ABOUT HERE]}

We now start analyzing different employment and economic outcomes for all individuals in the sample (5,582). Figure 2 shows the proportion of individuals working full-time (i.e. 35 hours per week or more), at ages $27-31$, by age at leaving home. Immediately, we can see how a higher proportion of young adults are working full-time if they left at 18 rather than at younger ages. This is likely attributable to the fact that age 18 is the typical age at which youth start their college education. The proportion working full-time declines slightly for those who have left at 19, 20, and 21 . From age 22 onwards the proportion working full-time is higher than among those who left at 18 (even if the difference is not statistically significant).

\section{[FIGURE 2 ABOUT HERE]}

The same pattern can be observed when we look at the number of hours worked per week (Figure 3) and job tenure (Figure 4) in 2011. We see an increase in hours worked and job stability among young adults in their late twenties if they leave their parental home at age 18, or when they are 21 years old and older.

\section{[FIGURES 3, 4, 5 ABOUT HERE]}

In Figure 5, we plot the average income from work earned in 2010 by all respondents based on the age at leaving home. The average income in 2010 of young Americans born between 1980 and 1984 is $\$ 33,033$ among those who left the parental home at age 18 , while it is below $\$ 25,300$ among those who left at age 17 or earlier. Remarkably, income is also lower among those who moved at ages 19, 20 and $21(\$ 29,535, \$ 27,936$, and $\$ 31,580$ respectively). The highest average 
income is observed among young adults who left their parents when they were 22 years old, who have earned $\$ 36,101$ in 2010 . These patterns describe an M-shaped relationship between income and age at leaving home. When we take into account the possibility of moving back in with parents, we find that the same pattern of average income holds for those who never moved back and for those who moved back in with their parents at least once. However, those who happened to move back tend to report an average income that is consistently lower, independently on the age at which they left, except for ages 18 and 19 (Results available upon request).

\section{Multivariate Analysis}

The bivariate associations that we have described so far show clear associations between the living arrangements of young adults and later economic and work outcomes. However, several factors could jointly influence both the timing and pathways of leaving home, and the likelihood to return, and later outcomes. We ran a series of regression models that allow us to control for some observed potential confounders and explore some important mediating factors. We discuss the results of these models referring to the three hypotheses put forward in Section 2.

\section{Age at Leaving Home (H1)}

Moving from Table 3, we now look at how age at leaving home is associated with the probability of working full-time, the job tenure measured in weeks, the number of hours worked per week in 2011, and the income from work in 2010. When we only consider the age at leaving home, controlling for gender, ethnicity and age at interview (Model 1), we find that leaving home before age 18 and at age 19-20 is associated with lower odds to be working more than 35 hours per week in 2011, with a shorter job tenure, with less hours of work per week, and with a lower annual work 
income. Therefore, consistently with H1, the relationship between age at leaving home and labour market outcomes is not linear. Moreover, labor market outcomes are significantly less favorable for women, Blacks, and Hispanics. The non-linear relationship with age generally holds also when we include additional demographic and socioeconomic controls (Model 2), although the coefficient for age 19-20 in the models for working full-time and job tenure are not significantly different from the reference group (leaving at age 18). Models on income show an M-shaped association between age at leaving home and income from work: income is lower for those who left before 18 years of age, at 19-20, and when 23 or older. Higher parental education is associated with better employment and economic outcomes (not significant for job tenure), and also having lived with biological parents until age 14, while a higher number of siblings is associated with slightly worse outcomes. Unstable economic conditions and health problems in childhood are also associated with worse employment and economic outcomes. Further regression models have been implemented as robustness checks, mainly testing interaction effects between age at leaving home and other key covariates. These analyses did not show a significant difference in the association between age at leaving home and labor market outcomes from the current analysis.

To sum up, consistently with $\mathrm{H} 1$ our analyses suggest that very early or late ages at leaving home are associated with a penalty later in life, and that normative ages (i.e. 18 years old) at leaving home are linked to better job market outcomes for young adults between age 27 and 31 .

\section{[TABLE 3 ABOUT HERE]}

\section{Pathways (H2) and Moving Back Home (H3)}

To start considering the pathways through which individuals leave the parental home, we split respondents into two groups: those who have never been enrolled in college and the rest (those 
who have ever been enrolled in college). Table 4 reports the results of our analyses on the subsample of those who never attended college (we here only report the results on income from work in 2010, while the results for other outcomes are available upon request). First, leaving the parental home before age 18 is associated with a lower income from work in 2010, with other ages not significantly different from age 18. Also the coefficient for ages equal or lower than 17 becomes not significant when we include control variables in Model (2). However, we can still estimate an M-shaped relationship between age at leaving home and income. We performed a likelihood-ratio test comparing the Model (2) with and without age at leaving home, and the test confirms that the goodness of fit improves when we include age at moving out. Moreover, as we can see in Model (3), moving back in with parents (H3) is negatively and significantly associated with later income from work within this group of respondents.

\section{[TABLES 4 ABOUT HERE]}

The findings so far seem to imply that there are optimal ages to leave the parental home (i.e. 18 and 21-22 years old), or that leaving too early or too late could be detrimental. Given the strong and well-documented relationship between educational attainment and subsequent employment opportunities and income (Harmon et al., 2003), in addition to the correlation between going to college and the decision to move out or not of the parental home, it might be that our results are purely driven by the educational attainment of those who attend college. For this reason, we repeat multivariate analyses on the subsample of those who have been enrolled in college at least once, and consider the possible pathways of leaving home. Only analyses on income from work in 2010 
is reported here (analyses focusing on working full-time, hours worked per week, and job tenure in 2011 shows robust and consistent results and are available upon request).

\section{[TABLE 5 ABOUT HERE]}

Table 5 reports the results of the analyses on income from work, for young adults who have been enrolled in college, with or without a college degree (Junior/Associate degree, Bachelor degree or more. A dummy variable for the attainment of junior/associate degree versus a Bachelor degree has been added to the model specification as a robustness check. Its coefficient is negative and significant, but its inclusion does not modify our results, and so it is not reported in the tables). Models (1) and (2) replicate the analyses performed earlier. These results confirm that leaving home before age 18, and at ages 19-20 is negatively and significantly (at $1 \%$ level in Model 1 , and at $10 \%$ level in Model 2) associated with income from work, as compared to leaving at age 18, when we do not consider the pathways of leaving home. From Model (3), we start to include the three possible pathways (leaving home to go to college, during college, after college) to test $\mathrm{H} 2$, using leaving home before college as our reference category. Leaving the parental home at ages $19-20$ and at 23 or older is significantly associated with lower income from work in 2010 , while leaving home to go to college, during or after college are positively associated with later income. Model (4) tests the H3 on those who have been enrolled in college, and shows that moving back in with parents is negatively associated with income for this subsample. Finally, Model (5) takes into account educational attainment, and shows that even when considering the level of education achieved, the pathways of leaving home and returning home, are significantly associated with subsequent income from employment.

Overall, the results show that the pathway of leaving home is significantly linked to subsequent economic outcomes, and in particular that leaving home before college is associated with lower 
future income. However, even conditional on the pathway of home leaving, leaving too late or at non-normative ages is associated with a penalty, while those leaving at age 18 are the better off. Returning to the parental home is consistently and negatively associated with subsequent economic outcomes.

\section{Discussion and Conclusion}

This study sheds light on the links between age at leaving home, the pathways of leaving home, returning home, and the subsequent economic and employment conditions of American young adults. Based on the existing literature, and in particular on capital accumulation and life course theories, we cast our first hypothesis (H1), i.e. that the age at leaving home has an inverted Ushaped association with subsequent labor market outcomes. Our findings confirm that there is a non-linear relationship between age at leaving home and subsequent outcomes, with the normative age 18 associated with better outcomes than surrounding ages. However, we do not find an inverted U-shaped association, but rather an M-shaped association between these two variables: leaving "too early" or leaving "too late" is detrimental for later employment and especially economic outcomes, but also leaving at non-normative ages, such as 19-20 years old. The findings suggest that there is an optimal age for leaving the parental home, i.e. 18 years of age, consistently with idea, within the life course approach, that age norms matter (Liefbroer \& Billari, 2010; Settersten, 1998; Settersten \& Hagestad, 1996). Even if age at leaving home is relatively low in the U.S. in comparison to other Western societies, and we only partially observe the negative side of leaving too late, our results are consistent with the interpretation based on studies focusing on Southern Europe (where instead we observe the negative effect of leaving late but not the negative effects 
of leaving too early, because the mean age at leaving home is already quite high) (Alesina \& Giuliano, 2007; Alessie et al., 2005; Billari \& Tabellini, 2011; Parisi, 2008).

Our second hypothesis $(\mathrm{H} 2)$ was related to the pathways out of the parental home for those who enroll in college. Our findings provide an insight on the importance of education, and showed that those who leave home to attend college or during college are later better off, when compared to those leaving home before or after college. Hence our second hypothesis is only partially supported, with a clear penalty for those who attend college and leave home before enrollment, even when controlling for the attainment of a college degree. However, there is no penalty associated to leaving home after college.

Our third hypothesis (H3) was related to the penalty suffered by young adults who return to the parental home: this is confirmed in all samples, and confirms that moving back in with parents is associated with negative employment and financial outcomes. This is of particular interest, given the increasing proportion of young adults that move back home after a period of independent living (Kaplan, 2012).

Our analyses suffer from two main limitations. First, as usual in observational studies, we are not in the position to ascertain causal links between the timing and pathways out of the parental home, and returning home, and subsequent labor market outcomes. Even if we controlled for the most important social-structural factors such as gender, ethnicity, parental education, and some early life health and socioeconomic characteristics, we could not take into account many other factors that jointly influence the independent variables and the outcomes (e.g. housing conditions, or access to scholarships). As common in the literature on penalties in the life course, a first step is to establish solid associations. Second, we used a single time point for our outcomes, and this time point is relatively early in the life course. It might well be that we underestimated the consequences 
of leaving and returning home, as these factors might lead to cumulative effects that create wider gaps later in life. On the contrary, it might also be that the "scars" of the trajectory out (or back in) of the parental home are healed soon and these differences do not become visible later. Only analyses with longer trajectories will help us solving this doubt. However, the results of this analysis confirm the need to understand the link between the transition to adulthood and subsequent economic and employment outcomes. Putting together our findings and those already existing in the literature, we can coherently show the M-shaped relationship between age at leaving home and labor market 'performance'. If in Southern Europe, late home leaving is detrimental for young adults, in the U.S. early and non-normative home leaving has the same effect on their economic conditions later on. Moreover, we cannot disregard the role of college attendance, and how the pathway of home leaving is also key to understand economic outcomes later in life. Future research should focus on long-term labor market outcomes, in order to understand whether the negative effects of early home leaving persist over time, or if there is a recuperation after the initial difficult period. This is especially important in the American context, given the financial crisis of 2008 and the fact that young adults were particularly affected by it (Grusky, Western, \& Wimer, 2011). 


\section{References}

Aassve, A., Arpino, B., \& Billari, F. C. (2013). Age norms on leaving home: multilevel evidence from the European Social Survey. Environment and Planning A, 45(2), 383-401.

Aassve, A., Billari, F. C., Mazzucco, S., \& Ongaro, F. (2002). Leaving home: a comparative analysis of ECHP data. Journal of European social policy, 12(4), 259-275.

Aassve, A., Davia, M. A., Iacovou, M., \& Mazzuco, S. (2007). Does Leaving Home Make You Poor? Evidence from 13 European Countries. European Journal of Population, 23(3-4), 315-338.

Alesina, A., \& Giuliano, P. (2007). The Power of the Family. Retrieved from Cambridge, MA:

Alessie, R., Brugiavini, A., \& Weber, G. (2005). Saving and Cohabitation: The Economic Consequences of Living with One's Parents in Italy and the Netherlands. Retrieved from Cambridge, MS:

Avery, R., Goldscheider, F., \& Speare, A. J. (1992). Feathered Nest Gilded Cage - Parental Income and Leaving Home in the Transition to Adulthood. Demography, 29(3), 375-388.

Billari, F. C. (2004). Becoming an Adult in Europe: A Macro(/Micro)-Demographic Perspective. Demographic Research Special Collections, 3(2), 15-44.

Billari, F. C., \& Liefbroer, A. C. (2007). Should I stay or should I go? The impact of age norms on leaving home. Demography, 44(1), 181-198.

Billari, F. C., \& Liefbroer, A. C. (2010). Towards a new pattern of transition to adulthood? Advances in Life Course Research, 15(2-3), 59-75.

Billari, F. C., Philipov, D., \& Baizán, P. (2001). Leaving Home in Europe: The Experience of Cohorts Born Around 1960. International Journal of Population Geography, 7, 339-356.

Billari, F. C., \& Rosina, A. (2004). Italian "latest-late" transition to adulthood: an exploration of its consequences on fertility. Genus, 60(1), 71-88.

Billari, F. C., \& Tabellini, G. (2011). Italians Are Late. Does It Matter? In J. B. Shoven (Ed.), Demography \& The Economy (pp. 371-412). Chicago: University of Chicago Press.

Buchmann, M. (1989). The Script of Life in Modern Society. Entry into Adulthood in a Changing World. Chicago: University of Chicago Press.

Buchmann, M. C., \& Kriesi, I. (2011). Transition to Adulthood in Europe. Annual Review of Sociology, 37, 23.21-23.23.

Card, D., \& Lemieux, T. (2000). Adapting to Circumstances: The Evolution of Work, School, and Living Arrangements Among North American Youth. In D. G. Blanchflower \& R. B. 
Freeman (Eds.), Youth Employment and Joblessness in Advanced Countries (pp. 171-213). Chicago, IL: University of Chicago Press.

Cherlin, A. J., Scabini, E., \& Rossi, G. (1997). Still in the Nest Delayed Home Leaving in Europe and the United States. Journal of Family Issues, 18(6), 572-575.

Da Vanzo, J., \& Goldscheider, F. K. (1990). Coming Home Again: Returns to the Parental Home of Young Adults. Population Studies, 44(2), 241-255. doi:10.1080/0032472031000144576

Elder, G. H. J. (1975). Age differentiation and the life course. Annual Review of Sociology, 1, 165190.

Esping-Andersen, G. (1999). Social foundations of postindustrial economies: Oxford University Press.

Furstenberg, F. F., Jr., Kennedy, S., McLoyd, V. C., Rumbaut, R. G., \& Settersten, R. A., Jr. (2004). Growing up is harder to do. Contexts, 3(3), 33-41.

Gangl, M. (2004). Welfare states and the scar effects of unemployment: a comparative analysis of the United States and West Germany. American Journal of Sociology, 109, 1319-1364.

Gangl, M. (2006). Scar effects of unemployment: an assessment of institutional complementarities. American Sociological Review, 71, 986-1013.

Goldscheider, F., \& Goldscheider, C. (1993). Whose Nest - a 2-Generational View of Leaving Home during the 1980s. Journal of Marriage and the Family, 55(4), 851-862.

Goldscheider, F., \& Goldscheider, C. (1994). Leaving and Returning Home in 20th-Century America. Population Bulletin, 48(4), 2-35.

Goldscheider, F. K., \& DaVanzo, J. (1986). Semiautonomy and Leaving Home in Early Adulthood. Social Forces, 65(1), 187-201. doi:10.2307/2578942

Goldscheider, F. K., \& Goldscheider, C. (1998). The effects of childhood family structure on leaving and returning home. Journal of Marriage and the Family, 60(3), 745-756.

Goldscheider, F. K., \& Waite, L. J. (1987). Nest-Leaving Patterns and the Transition to Marriage for Young Men and Women. Journal of Marriage and Family, 49(3), 507-516. doi: $10.2307 / 352196$

Granovetter, M. S. (1973). The Strength of Weak Ties. American Journal of Sociology, 78(6), 1360-1380.

Grusky, D. B., Western, B., \& Wimer, C. (Eds.). (2011). The Great Recession. New York, NY: Russel Sage Foundation. 
Halleröd, B., \& Westberg, A. (2006). Youth problem: What's the problem? A longitudinal study of incomes and economic hardship among Swedish youth. Acta Sociologica, 49(1), 83102.

Heckman, J. J., \& Rubinstein, Y. (2001). The Importance of Noncognitive Skills: Lessons from the GED Testing Program. American Economic Review, 91(2), 145-149.

Holdsworth, C. (1998). Leaving home in Spain: a regional analysis. International Journal of Population Geography, 4(4), 341-360. doi:10.1002/(sici)10991220(199812)4:4<341::Aid-ijpg113>3.0.Co;2-c

Hollister, M. N., \& Smith, K. E. (2014). Unmasking the Conflicting Trends in Job Tenure by Gender in the United States, 1983-2008. American Sociological Review, 79(1), 159-181. doi:doi:10.1177/0003122413514584

Iacovou, M. (2002). Regional differences in the transition to adulthood. Annals of the American Academy of Political and Social Science, 580(1), 40-69.

Kaplan, G. (2012). Moving Back Home: Insurance against Labor Market Risk. Journal of Political Economy, 120(3), 446-512.

Kidd, M. P., O'Leary, N., \& Sloane, P. (2017). The impact of mobility on early career earnings: A quantile regression approach for UK graduates. Economic Modelling, 62, 90-102. doi:https://doi.org/10.1016/j.econmod.2017.01.011

Leopold, T. (2012). The Legacy of Leaving Home: Long-Term Effects of Coresidence on Parent - Child Relationships. Journal of Marriage and Family, 74(3), 399-412. doi:10.1111/j.1741-3737.2012.00964.x

Liefbroer, A. C., \& Billari, F. C. (2010). Bringing Norms Back In: A Theoretical and Empirical Discussion of Their Importance for Understanding Demographic Behaviour. Population, Space and Place, 16(4), 287-305.

Mandic, S. (2008). Home-Leaving and its Structural Determinants in Western and Eastern Europe: An Exploratory Study. Housing Studies, 23(4), 615-637. doi:10.1080/02673030802112754

Modell, J., Furstenberg, F. F., Jr., \& Hershberg, T. (1976). Social change and transition to adulthood in historical perspective. Journal of Family History, 1(1), 7-32.

Mulder, C., \& Clark, W. A. V. (2000). Leaving home and leaving the state: Evidence from the United States. International Journal of Population Geography, 6, 423-437.

Mulder, C., Clark, W. A. V., \& Wagner, M. (2002). A comparative analysis of leaving home in the United States, the Netherlands and West Germany. Demographic Research, 7(17), 565592. 
Mulder, C. H., \& Clark, W. A. V. (2002). Leaving home for college and gaining independence. Environment and Planning A, 34(6), 981-999. doi:Doi 10.1068/A34149

Parisi, L. (2008). Leaving Home and the Chances of Being Poor: The Case of Young People in Southern European Countries. LABOUR, 22, 89-114. doi:10.1111/j.14679914.2008.00414.x

Qian, Z. (2012). During the Great Recession, More Young Adults Lived with Parents. Census Brief prepared for Project US2010. www.s4.brown.edu/us2010.

Ribar, D. C. (2015). Is Leaving Home a Hardship? Southern Economic Journal, 81(3), 598-618. doi:10.4284/0038-4038-2014.007

Rindfuss, R. R. (1991). The Young Adult Years: Diversity, Structural Change, and Fertility. Demography, 28(4), 493-512.

Settersten, R. A., Jr. (1998). A Time to Leave Home and A Time Never to Return? Age Constraints on the Living Arrangements of Young Adults. Social Forces, 76(4), 1373-1400. doi:10.1093/sf/76.4.1373

Settersten, R. A. J., \& Hagestad, G. O. (1996). What's the latest? Cultural age deadlines for family transitions. Gerontologist, 36(2), 178-188.

Settersten, R. A. J., \& Mayer, K. U. (1997). The Measurement of Age, Age Structuring, and the Life Course. Annual Review of Sociology, 23(1), 233-261.

Sironi, M., \& Furstenberg, F. F. (2012). Trends in the Economic Independence of Young Adults in the United States: 1973-2007. Population and Development Review, 38(4), 609-630. doi:10.1111/j.1728-4457.2012.00529.x

South, S. J., \& Lei, L. (2015). Failures-to-Launch and Boomerang Kids: Contemporary Determinants of Leaving and Returning to the Parental Home. Social Forces, 94(2), 863890. doi:10.1093/sf/sov064

Stone, J., Berrington, A., \& Falkingham, J. (2014). Gender, Turning Points, and Boomerangs: Returning Home in Young Adulthood in Great Britain. Demography, 51(1), 257-276. doi:10.1007/s13524-013-0247-8

Waite, L., Kobrin-Goldscheider, F., \& Witsberger, C. (1986). Non-family living and the erosion of traditional family orientations among young adults. American Sociological Review, 51(4), 541-554.

White, L., \& Lacy, N. (1997). The Effects of Age at Home Leaving and Pathways from Home on Educational Attainment. Journal of Marriage and the Family, 59(4), 982-995. 


\section{Tables}

Table 1. Descriptive Statistics (weighted)

Age at Interview, 2011

$\%$ Female

Ethnicity (\%)

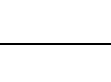

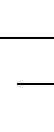

Whole Sample

Left Home

Mean/\%

28.8

50.2

Mean/\%

28.9

50.7

White

Black

Hispanic

Other ethnicity

Self-Reported Health 1997 (\%)

Excellen
Very Good
Good
Fai
Poo

\% Ever Left Parental Home

Age at Leaving Parental Home

$\%$ Ever Moved Back

Years of Education

$\%$ Ever enrolled in College

$\%$ With a College Degree

Parents' Years of Education

$\%$ Lived w/ Both Biological Parents until 14

Number of Siblings

$\%$ Experienced Hard Times in Childhood

$\%$ with Chronic Condition 1997

$\%$ with Problems that Limits School/Work 1997

Household Income 1997 - Quintiles (\%)

69.9

14.4

11.6

4.2

38.7

36.1

20.9

4.1

0.2

95.7

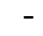

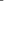

13.9

70.3

43.1

13.8

53.5

2.5

5.1

11.3

14.5
12.1

15.6

17.4

19.5

20.6

14.8

61.1

202 ( 3 years, 11.5 months)

40.3

35,474

Job tenure, average \# of weeks Average \# of hours worked per week Income (from work) past year (\$)

Number of Observations
70.7

14.1

11.1

4.1

38.9

36.2

20.9

3.9

0.2

20.1

42.1

14.0

70.4

43.6

13.8

53.1

2.5

5.2

11.2

14.1

11.9

15.6

17.2

19.8

20.9

14.6

61.6

200.7

40.4

35,893 
Table 2. Pathways of Leaving (and Returning) Home and College Attendance

Ever Moved Back

\begin{tabular}{|c|c|c|c|c|c|}
\hline $\begin{array}{l}\text { Leaving Home and } \\
\text { College Enrollment }\end{array}$ & \# & $\begin{array}{c}\text { Weighted } \\
\% \text { of } \\
5,582\end{array}$ & $\begin{array}{l}\text { Weighted } \\
\% \text { of those } \\
\text { going to } \\
\text { College, } \\
\mathrm{N}=3,787\end{array}$ & \# & $\begin{array}{l}\text { Weighted \% of } \\
\text { each category }\end{array}$ \\
\hline Not going to College & 1,795 & 29.6 & & 756 & $42.8(=756 / 1,795)$ \\
\hline $\begin{array}{l}\text { Leaving Before Going to College (at least } 3 \\
\text { months before college enrollment) }\end{array}$ & 991 & 16.7 & 23.7 & 461 & $47.5(=461 / 991)$ \\
\hline $\begin{array}{l}\text { Leaving to Go to College ( } \pm 3 \text { months } \\
\text { college enrollment) }\end{array}$ & 998 & 20.5 & 29.1 & 543 & $55.3(=543 / 998)$ \\
\hline $\begin{array}{l}\text { Leaving During College (at least } 3 \text { months } \\
\text { after enrollment) }\end{array}$ & 575 & 11.0 & 15.6 & 211 & $35.1(=211 / 575)$ \\
\hline \multirow[t]{2}{*}{$\begin{array}{l}\text { Going to College but Staying with Parents } \\
\text { and Leaving After }\end{array}$} & 1,223 & 22.3 & 31.6 & 359 & $28.2(=359 / 1,223)$ \\
\hline & 5,582 & 100.0 & 100.0 & & \\
\hline
\end{tabular}


Table 3. Age at Leaving Home and Employment Outcomes - Full sample

\begin{tabular}{|c|c|c|c|c|c|c|c|c|}
\hline & \multicolumn{2}{|c|}{$\begin{array}{c}\text { Y = Working } \\
\text { Fulltime }\end{array}$} & \multicolumn{2}{|c|}{$\begin{array}{c}\text { Y = Job Tenure } \\
\text { (Weeks) }\end{array}$} & \multicolumn{2}{|c|}{$\begin{array}{c}Y=\text { Hours Worked } \\
\text { per Week }\end{array}$} & \multicolumn{2}{|c|}{$\begin{array}{c}\text { Y = Work Income } \\
\text { (USD) in } 2010\end{array}$} \\
\hline & $(1)$ & (2) & (3) & (4) & $(5)$ & $(6)$ & $(7)$ & $(8)$ \\
\hline \multicolumn{9}{|l|}{ Age at leaving home (Ref: 18$)$} \\
\hline \multirow[t]{2}{*}{$\leq 17$} & $0.609 * * *$ & $0.743 * *$ & $-37.2 * * *$ & $-26.0 * * *$ & $-5.3 * * *$ & $-3.0 * * *$ & $-9934.7 * * *$ & $-5253.8 * * *$ \\
\hline & $0.51,0.73$ & $0.62,0.90$ & 6.80 & 6.90 & 0.9 & 0.90 & 1187.8 & 1168.5 \\
\hline \multirow[t]{2}{*}{$19-20$} & $0.810^{* *}$ & 0.865 & -10.40 & -7.50 & $-2.6^{* * *}$ & $-1.8^{*}$ & $-4278.6 * * *$ & $-2608.3 * *$ \\
\hline & $0.70,0.94$ & $0.74,1.01$ & 5.50 & 5.50 & 0.7 & 0.70 & 957.8 & 927.7 \\
\hline \multirow[t]{2}{*}{$21-22$} & 1.004 & 1.048 & 4.50 & 5.20 & -0.9 & -0.40 & -1444.4 & -257.8 \\
\hline & $0.84,1.19$ & $0.88,1.25$ & 6.30 & 6.30 & 0.9 & 0.80 & 1102.1 & 1067.4 \\
\hline \multirow{2}{*}{$\geq 23$} & 1.115 & 1.146 & 10.10 & 9.60 & 0 & 0.30 & $-4279.1 * * *$ & $-3497.7 * *$ \\
\hline & $0.93,1.34$ & $0.95,1.38$ & 6.70 & 6.60 & 0.9 & 0.90 & 1154.7 & 1120.4 \\
\hline \multirow[t]{2}{*}{ Female } & $0.572 * * *$ & $0.558 * * *$ & $-18.7 * * *$ & $-20.4 * * *$ & $-5.7 * * *$ & $-5.7 * * *$ & $-9717.9 * * *$ & $-9403.7 * * *$ \\
\hline & $0.51,0.64$ & $0.50,0.63$ & 4.10 & 4.10 & 0.5 & 0.50 & 707.4 & 687.5 \\
\hline \multicolumn{9}{|l|}{ Ethnicity (Ref: White) } \\
\hline \multirow[t]{2}{*}{ Black } & $0.595^{* * *}$ & $0.743 * * *$ & $-42.7 * * *$ & $-29.8 * * *$ & $-5.9 * * *$ & $-3.4 * * *$ & $-12137.5 * * *$ & $-6854.1 * * *$ \\
\hline & $0.52,0.68$ & $0.64,0.86$ & 4.90 & 5.30 & 0.7 & 0.70 & 848.9 & 900.8 \\
\hline \multirow[t]{2}{*}{ Hispanic } & 0.913 & 1.139 & $-11.7^{*}$ & -6.10 & $-2.0 * *$ & 0.60 & $-5649.7 * * *$ & -487.9 \\
\hline & $0.79,1.06$ & $0.96,1.35$ & 5.50 & 6.00 & 0.7 & 0.80 & 956.6 & 1015.4 \\
\hline \multirow[t]{2}{*}{ Other Ethnicity } & 0.982 & 0.945 & -10.00 & -10.50 & 0.2 & -0.30 & $4797.5^{*}$ & $4230.0 *$ \\
\hline & $0.71,1.36$ & $0.67,1.32$ & 12.10 & 12.00 & 1.6 & 1.60 & 2101.5 & 2030.9 \\
\hline \multirow[t]{2}{*}{ Age at interview, 2011} & $1.055^{* *}$ & $1.056 * *$ & $14.5 * * *$ & $14.3 * * *$ & $0.5^{* *}$ & $0.5^{* *}$ & $1987.1 * * *$ & $1992.3 * * *$ \\
\hline & $1.01,1.10$ & $1.01,1.10$ & 1.40 & 1.40 & 0.2 & 0.20 & 249 & 240.8 \\
\hline \multirow[t]{2}{*}{ Parents' years of education } & & $1.035 * *$ & & -1.10 & & $0.5 * * *$ & & $837.4 * * *$ \\
\hline & & $1.01,1.06$ & & 0.80 & & 0.10 & & 134.5 \\
\hline \multirow[t]{2}{*}{ Lived w/ both parents until 14} & & $1.189 * *$ & & $12.7 * *$ & & $1.7 * *$ & & $4741.4 * * *$ \\
\hline & & $1.05,1.35$ & & 4.60 & & 0.60 & & 775.7 \\
\hline \multirow[t]{2}{*}{ Number of Siblings } & & $0.960 * *$ & & $-2.2 *$ & & $-0.3^{*}$ & & -243.6 \\
\hline & & $0.94,0.98$ & & 0.90 & & 0.10 & & 158.5 \\
\hline \multicolumn{9}{|l|}{ Self Rep Health (Ref: Excellent) } \\
\hline \multirow[t]{2}{*}{ Very good } & & 1.006 & & 1.80 & & 0.00 & & $-3037.5^{* * *}$ \\
\hline & & $0.88,1.15$ & & 4.7 & & 0.6 & & 801.3 \\
\hline
\end{tabular}




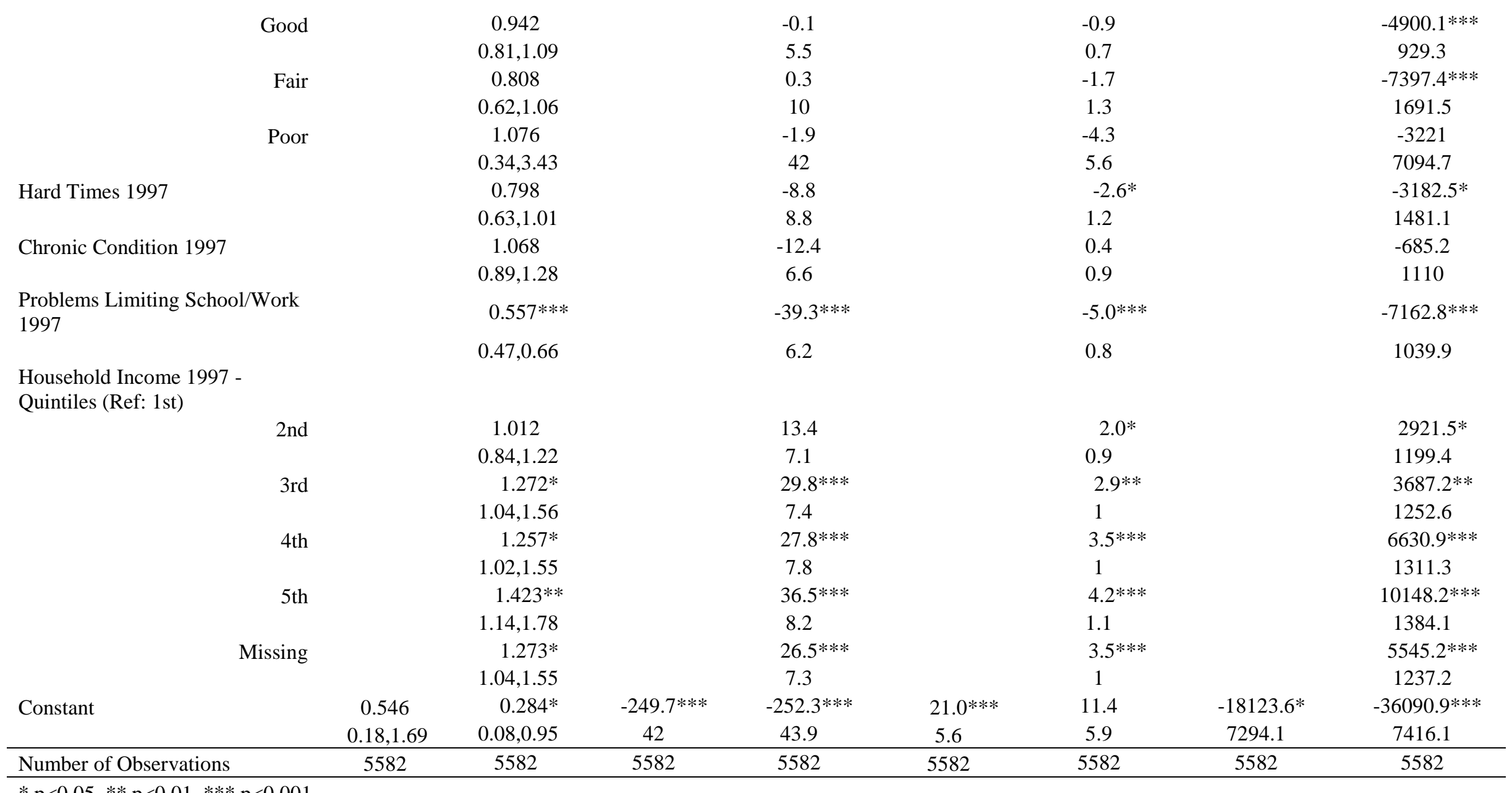

$* \mathrm{p}<0.05, * * \mathrm{p}<0.01, * * * \mathrm{p}<0.001$ 
Table 4. Age at Leaving Home and Income - Never enrolled in College

\begin{tabular}{|c|c|c|c|}
\hline & \multicolumn{3}{|c|}{$\mathrm{Y}=$ Work Income (USD) in 2010} \\
\hline & $(1)$ & $(2)$ & $(3)$ \\
\hline \multicolumn{4}{|l|}{ Age at leaving home (Ref: 18) } \\
\hline \multirow{2}{*}{0} & $-3574.1 *$ & -2726.2 & -2298.7 \\
\hline & 1451.5 & 1431.6 & 1427.6 \\
\hline \multirow[t]{2}{*}{$19-20$} & -13.7 & -376.6 & -664.2 \\
\hline & 1367.1 & 1348.1 & 1342.8 \\
\hline \multirow[t]{2}{*}{$21-22$} & 2453.4 & 1677.9 & 1202.2 \\
\hline & 1535.4 & 1516.6 & 1512.7 \\
\hline \multirow[t]{2}{*}{$\geq 23$} & -2413.1 & -2880.9 & $-3495.7 *$ \\
\hline & 1572 & 1560.5 & 1558.8 \\
\hline \multirow[t]{2}{*}{ Female } & $-11923.6 * * *$ & $-11540.9 * * *$ & $-11844.9 * * *$ \\
\hline & 904.6 & 898.6 & 896.6 \\
\hline \multicolumn{4}{|l|}{ Ethnicity (Ref: White) } \\
\hline \multirow[t]{2}{*}{ Black } & $-11574.7 * * *$ & $-10123.8 * * *$ & $-9982.3 * * *$ \\
\hline & 1056.7 & 1130.6 & 1125.3 \\
\hline \multirow[t]{2}{*}{ Hispanic } & $-2929.9 *$ & -1863 & -1866 \\
\hline & 1150.5 & 1274.4 & 1267.8 \\
\hline \multirow[t]{2}{*}{ Other Ethnicity } & -572.7 & -0.9 & 801 \\
\hline & 3718.2 & 3658.8 & 3644.6 \\
\hline \multirow[t]{2}{*}{ Age at interview, 2011} & $787.5^{*}$ & $831.3 * *$ & $814.0 * *$ \\
\hline & 314.8 & 310.9 & 309.4 \\
\hline \multirow[t]{2}{*}{ Parents' years of education } & & 325.9 & 330.3 \\
\hline & & 203 & 202 \\
\hline \multirow[t]{2}{*}{ Lived w/ both parents until 14} & & $2835.7 * *$ & $2844.0 * *$ \\
\hline & & 1018.8 & 1013.6 \\
\hline \multirow[t]{2}{*}{ Number of Siblings } & & 178.4 & 176.8 \\
\hline & & 178.9 & 178 \\
\hline \multicolumn{4}{|l|}{ Self Rep Health (Ref: Excellent) } \\
\hline \multirow[t]{2}{*}{ Very good } & & $-2248.0 *$ & -2155.9 \\
\hline & & 1111.7 & 1106.2 \\
\hline \multirow[t]{2}{*}{ Good } & & $-2757.5^{*}$ & $-2668.6^{*}$ \\
\hline & & 1146.1 & 1140.4 \\
\hline \multirow[t]{2}{*}{ Fair } & & $-3632.4 *$ & -3358 \\
\hline & & 1794.9 & 1786.8 \\
\hline \multirow[t]{2}{*}{ Poor } & & 1237.4 & 2962.5 \\
\hline & & 6678.9 & 6656.3 \\
\hline \multirow[t]{2}{*}{ Hard Times 1997} & & -893.6 & -696.8 \\
\hline & & 1572.4 & 1565 \\
\hline \multirow[t]{2}{*}{ Chronic Condition 1997} & & 544.6 & 639.4 \\
\hline & & 1388.6 & 1381.7 \\
\hline \multirow[t]{2}{*}{ Problems Limiting School/Work 1997} & & $-5695.2 * * *$ & $-5497.4 * * *$ \\
\hline & & 1114.6 & 1109.8 \\
\hline \multicolumn{4}{|l|}{$\begin{array}{l}\text { Household Income } 1997 \text { - Quintiles (Ref: } \\
\text { 1st) }\end{array}$} \\
\hline 2nd & & $2744.3^{*}$ & $2918.0 *$ \\
\hline & & 1301.7 & 1295.6 \\
\hline
\end{tabular}




\begin{tabular}{|c|c|c|c|}
\hline \multirow[t]{2}{*}{ 3rd } & & $4866.4 * *$ & $5081.5 * * *$ \\
\hline & & 1493.9 & 1487 \\
\hline \multirow[t]{2}{*}{ 4th } & & $5889.2 * * *$ & $6064.9 * * *$ \\
\hline & & 1693.1 & 1684.9 \\
\hline \multirow[t]{2}{*}{ 5th } & & 3086.2 & 3313.2 \\
\hline & & 2083.7 & 2073.7 \\
\hline \multirow[t]{7}{*}{ Missing } & & $4283.4 * *$ & $4193.3 * *$ \\
\hline & & 1447.2 & 1439.9 \\
\hline & & & $-3998.3 * * *$ \\
\hline & & & 910.4 \\
\hline & 5305 & -2236.2 & -96.9 \\
\hline & 9281.3 & 9638.9 & 9601.9 \\
\hline & 1795 & 1795 & 1795 \\
\hline
\end{tabular}

$* \mathrm{p}<0.05, * * \mathrm{p}<0.01, * * * \mathrm{p}<0.001$ 
Table 5. Age, Pathways and Income - Ever enrolled in College

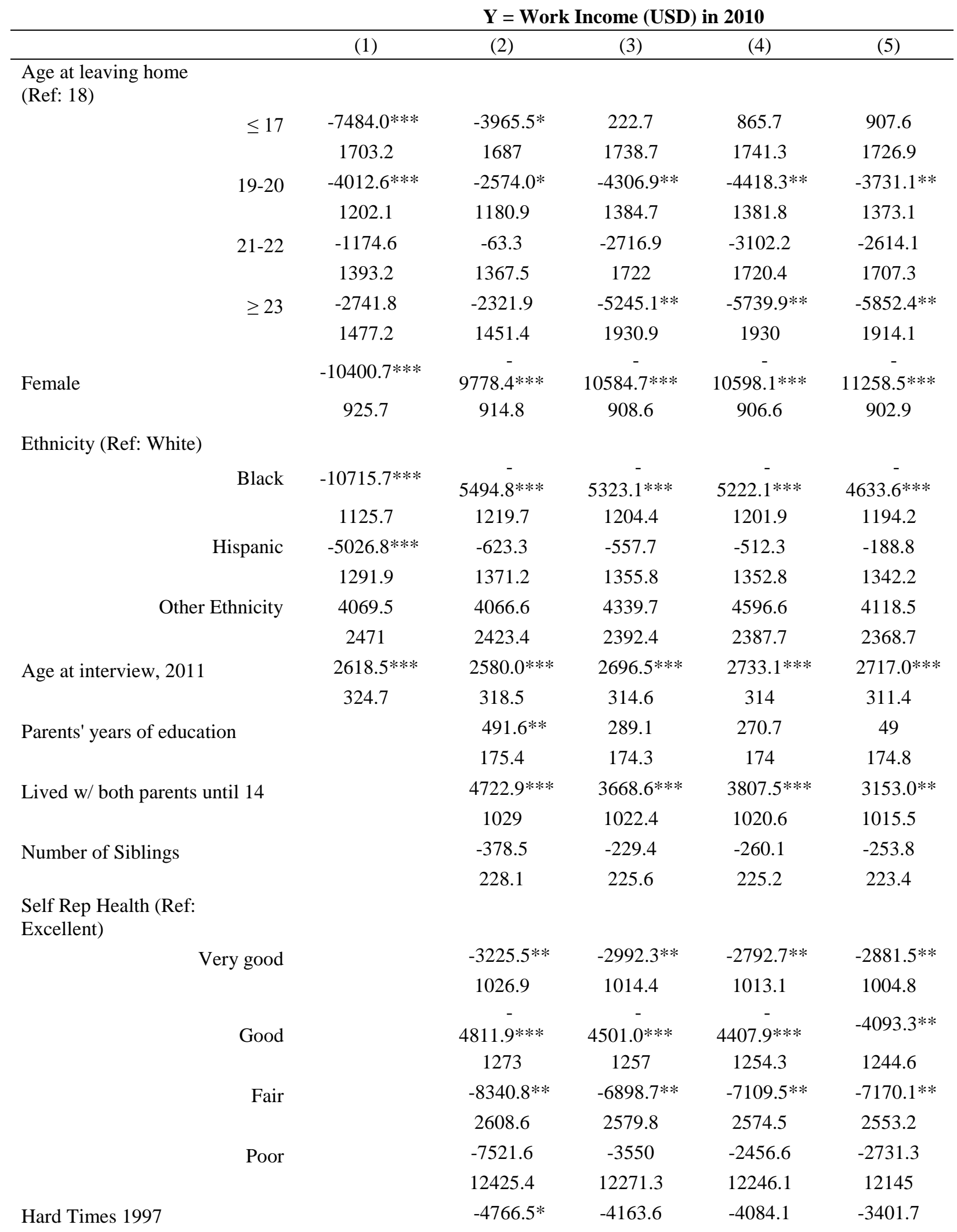


Chronic Condition 1997

Problems Limiting School/Work 1997

Household Income 1997 Quintiles (Ref: 1st)

2nd
3 rd
4 th
5 th

Missing

Pathway (Ref: Left before

College)

Left to go to college

Left during college

Left after college

Ever moved back

College Degree

$\begin{array}{cccc}2232.9 & 2205.1 & 2200.1 & 2183.6 \\ -1480.9 & -1670.4 & -1574.6 & -1648 \\ 1491.5 & 1472.4 & 1469.2 & 1457.1 \\ - & & & \\ 5628.7 * * * & -4602.3 * * & -4522.9 * * & -3466.4 * \\ 1584 & 1566.9 & 1563.4 & 1556.1\end{array}$

$\begin{array}{cccc}3379.1 & 2908.5 & 2902.9 & 2634.3 \\ 1793 & 1772.7 & 1768.7 & 1754.4 \\ 2598.1 & 1603.5 & 1458.5 & 1324.1 \\ 1778.2 & 1758.7 & 1755.1 & 1740.7 \\ 5945.1 * * & 4605.5 * & 4612.5 * * & 4208.2 * \\ 1811.5 & 1793.8 & 1789.7 & 1775.6 \\ 9892.5 * * * & 8347.8 * * * & 8371.8 * * * & 7762.0 * * * \\ 1862.2 & 1844.6 & 1840.4 & 1826.8 \\ 5291.4 * * & 3938.4 * & 3838.7 * & 3442.0 * \\ 1773.6 & 1755.8 & 1752 & 1738.2\end{array}$

\begin{tabular}{ccc}
$10831.5^{* * * *}$ & $11202.4 * * *$ & $8788.4 * * *$ \\
1378.9 & 1378.5 & 1400.1 \\
& & \\
$14222.9 * * *$ & $14119.5 * * *$ & $11517.3 * * *$ \\
1636.5 & 1632.9 & 1651.9 \\
$10566.4 * * *$ & $10304.7 * * *$ & $9487.3 * * *$ \\
1543.8 & 1541.5 & 1532.2 \\
& - & - \\
& $3937.8^{* * * *}$ & $3492.2^{* * *}$ \\
& 924 & 918 \\
- & & $7965.0 * * *$ \\
$52449.0 * * *$ & $51624.6 * * *$ & $51080.7 * * *$ \\
9722.2 & 9702 & 9622.1 \\
\hline 3787 & 3787 & 3787
\end{tabular}

$* \mathrm{p}<0.05, * * \mathrm{p}<0.01, * * *$

$-33222.5 * * *$ $45722.6^{* * * *}$ 9814.2

3787
$\mathrm{p}<0.001$ 
Figures

Figure 1. Age at leaving the parental home, $N=\mathbf{5 , 5 8 2}$

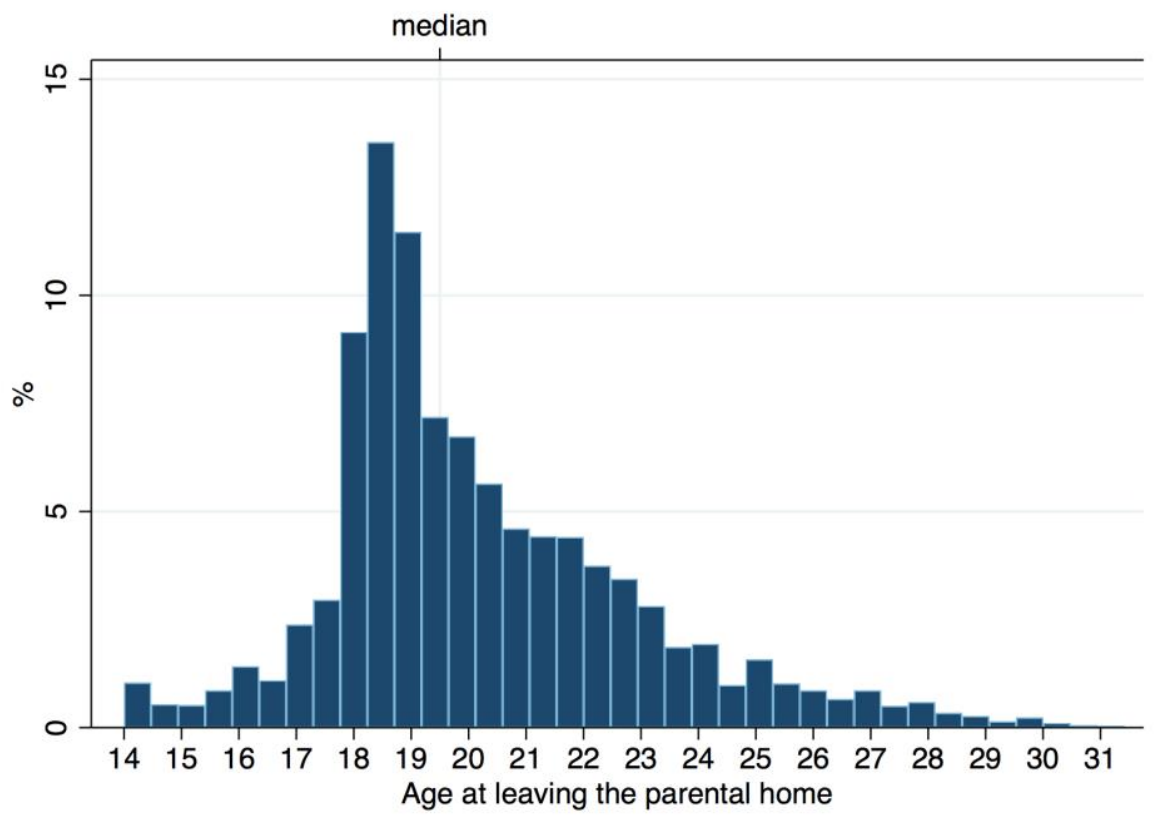

Figure 2. Age at leaving the parental home and \% working fulltime, 2011

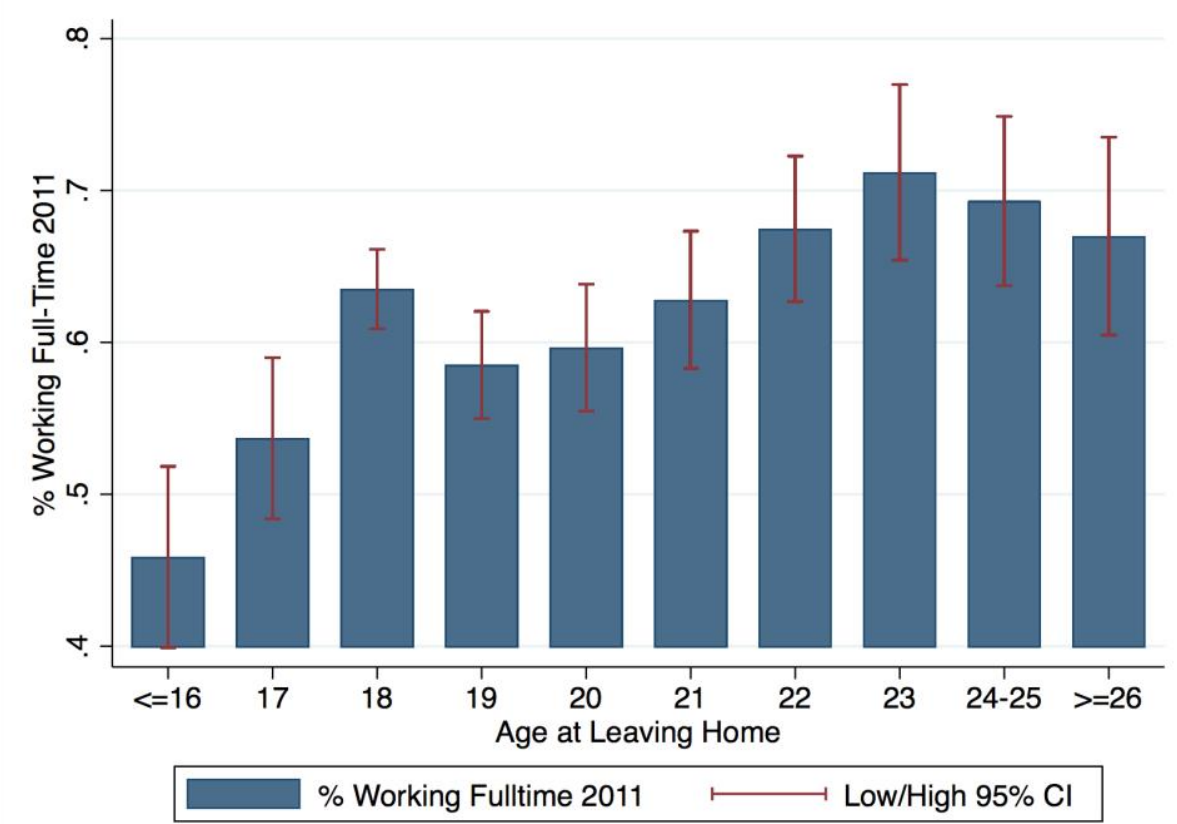


Figure 3. Age at leaving the parental home and Hours worked per week, 2011

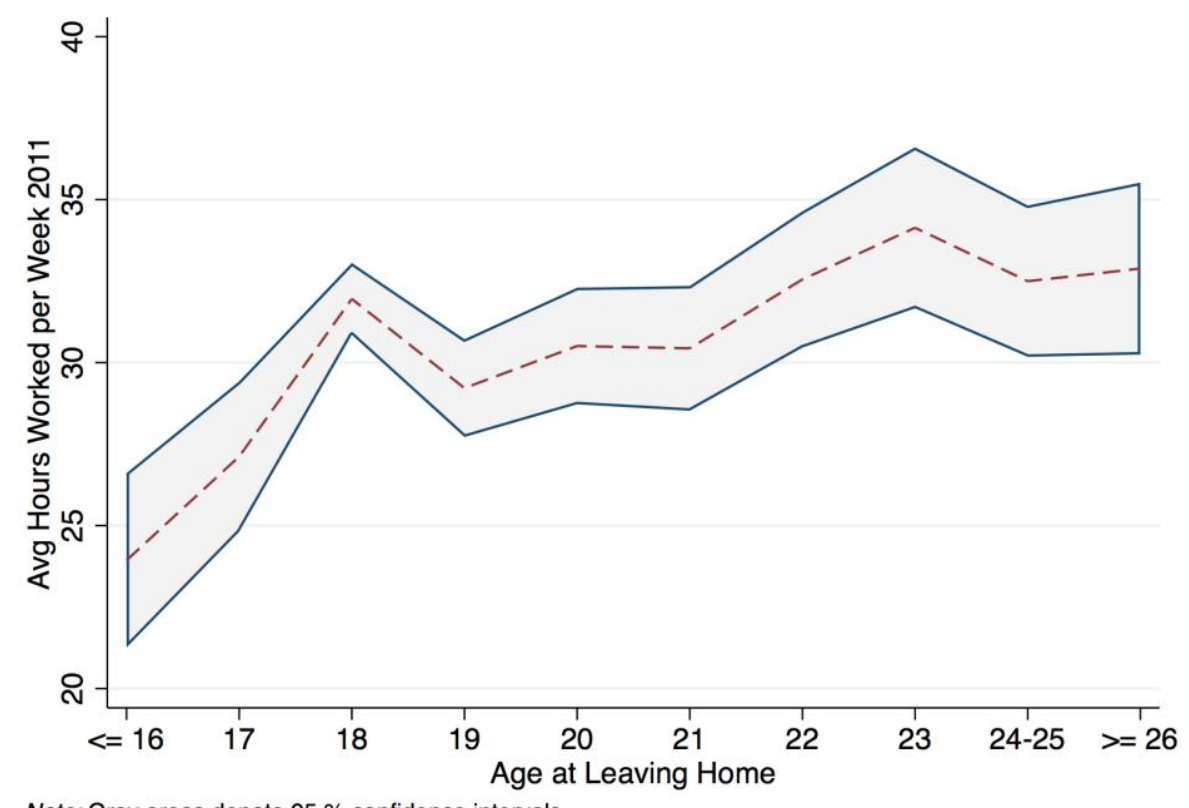

Note: Gray areas denote $95 \%$ confidence intervals

Figure 4. Age at leaving the parental home and Job Tenure, 2011

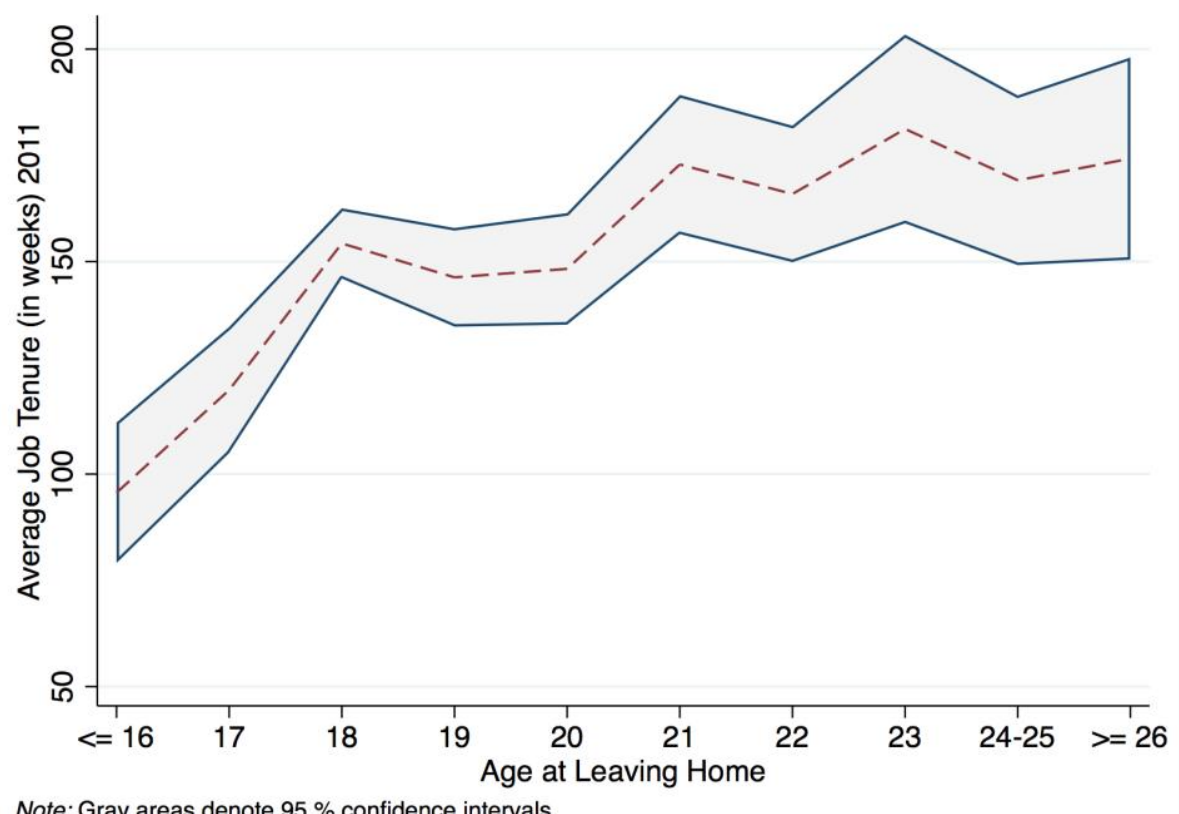

Note: Gray areas denote $95 \%$ confidence intervals 
Figure 5. Age at leaving the parental home and Average income (USD) in 2010

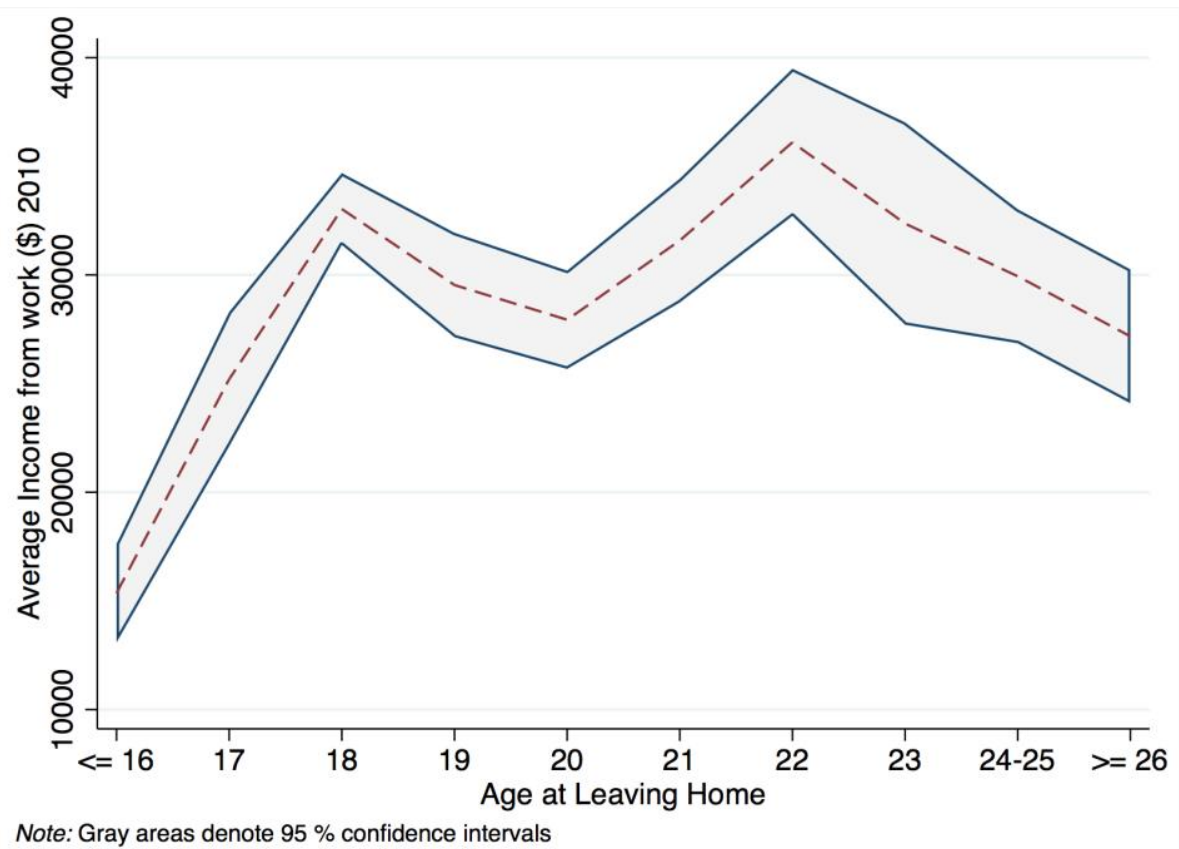

Note: Gray areas denote $95 \%$ confidence intervals 


\section{Appendix}

Table A1. Age at Leaving Home and Income - Full sample, by gender + interaction gender*race

\begin{tabular}{|c|c|c|c|c|c|c|}
\hline \multirow[t]{2}{*}{$\begin{array}{l}Y=\text { Work Income } \\
\text { (USD) in } 2010\end{array}$} & \multicolumn{2}{|c|}{ Men } & \multicolumn{2}{|c|}{ Women } & \multicolumn{2}{|c|}{ Interaction Gender*Race } \\
\hline & (1) & (2) & (3) & (4) & $(5)$ & (6) \\
\hline \multicolumn{7}{|l|}{$\begin{array}{l}\text { Age at leaving home } \\
\text { (Ref: 18) }\end{array}$} \\
\hline \multirow[t]{2}{*}{$\leq 17$} & $-9994.1 * * *$ & $-5078.0 * *$ & $-9924.3 * * *$ & $-5483.5 * * *$ & $-9963.7 * * *$ & $-5310.2 * * *$ \\
\hline & 1964.4 & 1947 & 1396.40 & 1358.50 & 1185.3 & 1165.80 \\
\hline \multirow[t]{2}{*}{$19-20$} & $-4231.5 * *$ & -2711.1 & $-4613.1 * * *$ & $-3018.1 * *$ & $-4523.9 * * *$ & $-2856.2^{* *}$ \\
\hline & 1569.1 & 1534 & 1138.1 & 1089.3 & 956.2 & 926.2 \\
\hline \multirow[t]{2}{*}{$21-22$} & -1642.8 & -538.2 & -1729.3 & -732.2 & -1695.3 & -505.4 \\
\hline & 1791 & 1758.8 & 1318 & 1258.8 & 1100.1 & 1065.4 \\
\hline \multirow[t]{2}{*}{$\geq 23$} & $-4834.0 * *$ & $-3864.7 *$ & $-3916.2 * *$ & $-3292.0 *$ & $-4458.0 * * *$ & $-3677.3 * *$ \\
\hline & 1802.3 & 1767.8 & 1444.5 & 1383.2 & 1152.2 & 1117.9 \\
\hline \multirow[t]{2}{*}{ Female } & - & - & - & - & -2648 & -1009.3 \\
\hline & & & & & 4096.4 & 3952.5 \\
\hline \multicolumn{7}{|l|}{ Race (Ref: White) } \\
\hline \multirow[t]{2}{*}{ Black } & $-16883.6 * * *$ & $-11287.5 * * *$ & $-7759.3 * * *$ & $-2514.6^{*}$ & $-16878.2 * * *$ & $-11366.4 * * *$ \\
\hline & 1372.7 & 1471.6 & 1019.6 & 1068.3 & 1220.1 & 1236.6 \\
\hline \multirow[t]{2}{*}{ Hispanic } & $-6905.7 * * *$ & -2094.1 & $-4572.6 * * *$ & 1141.6 & $-6773.7 * * *$ & -1715.7 \\
\hline & 1524.3 & 1625.3 & 1162.7 & 1226.8 & 1355.5 & 1370.4 \\
\hline \multirow[t]{2}{*}{ Other race } & -742.6 & -2011.3 & $9379.5 * * *$ & $9057.8 * * *$ & -662.1 & -1932.4 \\
\hline & 3490 & 3396 & 2462.2 & 2354.9 & 3110.6 & 3001.8 \\
\hline \multirow[t]{2}{*}{ Age at interview, 2011} & $3022.7 * * *$ & $2976.9 * * *$ & $1052.6 * * *$ & $1077.8 * * *$ & $1996.9 * * *$ & $2003.8 * * *$ \\
\hline & 402.3 & 392.8 & 298.8 & 285.5 & 248.4 & 240.3 \\
\hline \multirow{2}{*}{$\begin{array}{l}\text { Parents' years of } \\
\text { education }\end{array}$} & & & & & & \\
\hline & & $771.5^{* * *}$ & & $896.9 * * *$ & & $828.1 * * *$ \\
\hline \multirow{2}{*}{\multicolumn{7}{|c|}{ Lived w/ both parents }} \\
\hline & & & & & & \\
\hline until 14 & & 1259.5 & & $\begin{array}{r}5005.1 \\
923.8\end{array}$ & & 773.8 \\
\hline \multirow[t]{2}{*}{ Number of Siblings } & & -125 & & $-383.2 *$ & & -266.3 \\
\hline & & 267.6 & & 182.4 & & 158.1 \\
\hline \multicolumn{7}{|l|}{$\begin{array}{l}\text { Self Rep Health } \\
\text { (Ref: Excellent) }\end{array}$} \\
\hline \multirow[t]{2}{*}{ Very good } & & $-3820.1 * *$ & & -1819.4 & & $-2890.6 * * *$ \\
\hline & & 1268.9 & & 982.1 & & 799.6 \\
\hline \multirow[t]{2}{*}{ Good } & & $-5889.0 * * *$ & & $-3941.8 * * *$ & & $-4907.8 * * *$ \\
\hline & & 1537.4 & & 1093.4 & & 926.9 \\
\hline Fair & & $-9132.5 * *$ & & $-6236.7 * *$ & & $-7529.0 * * *$ \\
\hline & & 2958.3 & & 1903.4 & & 1687.2 \\
\hline Poor & & -5166.1 & & -3868.3 & & -3255.1 \\
\hline & & 16583.1 & & 6951.9 & & 7077.1 \\
\hline Hard Times 1997 & & $-5002.0 *$ & & -1090.1 & & $-3040.5^{*}$ \\
\hline & & 2386.3 & & 1777.6 & & 1477.3 \\
\hline Chronic Condition & & & & & & \\
\hline 1997 & & -2860.8 & & 1684.7 & & -719.4 \\
\hline & & 1737.3 & & 1371.7 & & 1107.2 \\
\hline Problems Limiting & & & & & & \\
\hline School/Work 1997 & & $-6577.5 * * *$ & & $-7861.5 * * *$ & & $-7206.7 * * *$ \\
\hline & & 1549.7 & & 1360.9 & & 1037.2 \\
\hline Household Income & & & & & & \\
\hline 1997 & & 3505.2 & & 2447.7 & & $2907.2 *$ \\
\hline
\end{tabular}


- Quintiles (Ref: 1st)

$\begin{array}{ccc}\text { 2nd } & 1952.9 & 1422.3 \\ & 5097.3^{*} & 2336.4 \\ \text { 3rd } & 2034.2 & 1491.6 \\ & 7401.6^{* * *} & 5629.8^{* * *} \\ \text { 4th } & 2140.9 & 1550.9 \\ & 8837.0^{* * *} & 11514.0^{* * *} \\ 5 \text { th } & 2236.3 & 1653.2 \\ & 6618.2^{* *} & 4420.1 * * \\ \text { sing } & 2028.1 & 1457.8\end{array}$

1196.3

$3668.5^{* *}$

1249.3

$6564.9^{* * *}$

1307.9

$10116.2 * * *$

1380.5

$5558.1 * * *$

1234.1

Female*Race

(Ref: men - White)

Female*White

Female*Black

Female*Hispanic

\begin{tabular}{lcccccc} 
& & & & 4408 & 4251.7 \\
Constant & $-46769.3^{* * *}$ & $-62797.6^{* * *}$ & -1881.2 & $-20633.1^{*}$ & $-16700.8^{*}$ & $-34551.6^{* * *}$ \\
\hline $\mathrm{N}$ & 11776.3 & 12083.3 & 8746.7 & 8783.8 & 7280.1 & 7402.9 \\
\hline$* \mathrm{p}<0.05, * * \mathrm{p}<0.01, * * * \mathrm{p}<0.001$ & 2718 & 2718 & 2864 & 2864 & 5582 & 5582 \\
\hline
\end{tabular}


Table A2. Age at Leaving Home and Income - Never enrolled in College, by gender + interaction gender*race

\begin{tabular}{|c|c|c|c|c|c|c|c|c|c|}
\hline \multirow[t]{2}{*}{$\begin{array}{l}Y=\text { Work Income } \\
\text { (USD) in } 2010\end{array}$} & \multicolumn{3}{|c|}{ Men } & \multicolumn{3}{|c|}{ Women } & \multicolumn{3}{|c|}{ Interaction Gender*Race } \\
\hline & (1) & (2) & (3) & (4) & (5) & $(6)$ & (7) & $(8)$ & (9) \\
\hline \multicolumn{10}{|l|}{$\begin{array}{l}\text { Age at leaving home } \\
\text { (Ref: } 18)\end{array}$} \\
\hline$\leq 17$ & -4396.1 & -3101 & -2411.2 & -2703.8 & -2531.4 & -2471 & $-3581.0 *$ & -2747.8 & -2343.8 \\
\hline & 2324.8 & 2296.5 & 2278.7 & 1543 & 1531.1 & 1534.9 & 1442 & 1422.2 & 1418.5 \\
\hline $19-20$ & -610.3 & -1366.1 & -1868.5 & -218 & -391.2 & -432.3 & -381.1 & -701.1 & -979.3 \\
\hline & 2192 & 2170.7 & 2151.9 & 1461.1 & 1447.7 & 1449.8 & 1361.5 & 1342 & 1337.2 \\
\hline $21-22$ & 1816.3 & 642.4 & -386.7 & 2404.9 & 1964.7 & 1924.3 & 2135.5 & 1394 & 934.8 \\
\hline & 2417.9 & 2394.5 & 2381.3 & 1672.9 & 1656.3 & 1658.2 & 1526.6 & 1507.4 & 1504 \\
\hline$\geq 23$ & -4485.3 & -4632.2 & $-5673.1 *$ & -42 & -791.8 & -877.9 & -2582.3 & -3013.3 & $-3606.5^{*}$ \\
\hline & 2456.9 & 2442.1 & 2428.6 & 1730 & 1727.9 & 1734.4 & 1562.1 & 1550.1 & 1549 \\
\hline \multirow[t]{2}{*}{ Female } & & & & & & & -7485.4 & -4287.2 & -5974.7 \\
\hline & & & & & & & 7699.4 & 7583.7 & 7557.6 \\
\hline \multicolumn{10}{|l|}{ Race (Ref: White) } \\
\hline \multirow[t]{2}{*}{ Black } & $-16144.2 * * *$ & $-14341.2 * * *$ & $-13954.8 * * *$ & $-5380.1 * * *$ & $-3976.5 * *$ & $-3981.4 * *$ & $-16298.6^{* * *}$ & $-14734.3 * * *$ & $14495.6^{-} * * *$ \\
\hline & 1620.6 & 1744.3 & 1729 & 1191.7 & 1277.3 & 1277.8 & 1384.5 & 1433.7 & 1427.9 \\
\hline \multirow[t]{2}{*}{ Hispanic } & $-5413.8 * *$ & $-4173.4 *$ & $-4230.1 *$ & 227.8 & 1584.1 & 1579.4 & $-5504.0 * * *$ & $-4401.3 * *$ & $-4464.3 * *$ \\
\hline & 1798.2 & 1981.8 & 1962.1 & 1256.1 & 1418.9 & 1419.5 & 1538.1 & 1617.6 & 1609.9 \\
\hline \multirow[t]{2}{*}{ Other race } & -5737.5 & -7317.4 & -4473.1 & 3643.6 & 5352.6 & 5402.4 & -5718.3 & -6988.6 & -5260.6 \\
\hline & 7404.8 & 7260.5 & 7215.2 & 3359.8 & 3339.1 & 3341.4 & 6341.2 & 6229.4 & 6212.8 \\
\hline \multirow[t]{2}{*}{ Age at interview, 2011} & 757.7 & 744.8 & 734.5 & 610.9 & 644.1 & 640.3 & $701.4 *$ & $740.2 *$ & $726.1 *$ \\
\hline & 495.7 & 488.9 & 484 & 342.4 & 341.4 & 341.6 & 313.2 & 309.4 & 307.9 \\
\hline \multirow[t]{2}{*}{ Parents' years of education } & & 395.4 & 427 & & 235.7 & 233.8 & & 306.9 & 312.7 \\
\hline & & 325.4 & 322.2 & & 216.8 & 216.9 & & 201.7 & 200.7 \\
\hline \multicolumn{10}{|l|}{ Lived w/ both parents } \\
\hline \multirow[t]{2}{*}{ until 14} & & $4399.6^{* *}$ & $4269.4 * *$ & & 646.9 & 665.6 & & $2665.1 * *$ & $2666.9 * *$ \\
\hline & & 1558.8 & 1543.5 & & 1165.8 & 1166.7 & & 1013.6 & 1008.7 \\
\hline \multirow[t]{2}{*}{ Number of Siblings } & & $568.3^{*}$ & $596.5^{*}$ & & -323.3 & -325.6 & & 155.5 & 155.7 \\
\hline & & 286.1 & 283.3 & & 193.2 & 193.4 & & 177.8 & 177 \\
\hline \multicolumn{10}{|l|}{$\begin{array}{l}\text { Self Rep Health } \\
\text { (Ref: Excellent) }\end{array}$} \\
\hline \multirow[t]{2}{*}{ Very good } & & -2656.5 & -2727.9 & & -1862 & -1819.6 & & -2066.8 & -1988.1 \\
\hline & & 1671.6 & 1655.1 & & 1314.3 & 1316.6 & & 1105.9 & 1100.8 \\
\hline \multirow[t]{2}{*}{ Good } & & -2670.6 & -2651 & & $-2789.8 *$ & $-2758.4^{*}$ & & $-2623.4^{*}$ & $-2547.2 *$ \\
\hline & & 1800.9 & 1782.9 & & 1286.6 & 1288.2 & & 1141.8 & 1136.5 \\
\hline Fair & & -4748.9 & -4742.5 & & -2991.5 & -2894.6 & & $-3670.4^{*}$ & -3407.4 \\
\hline
\end{tabular}




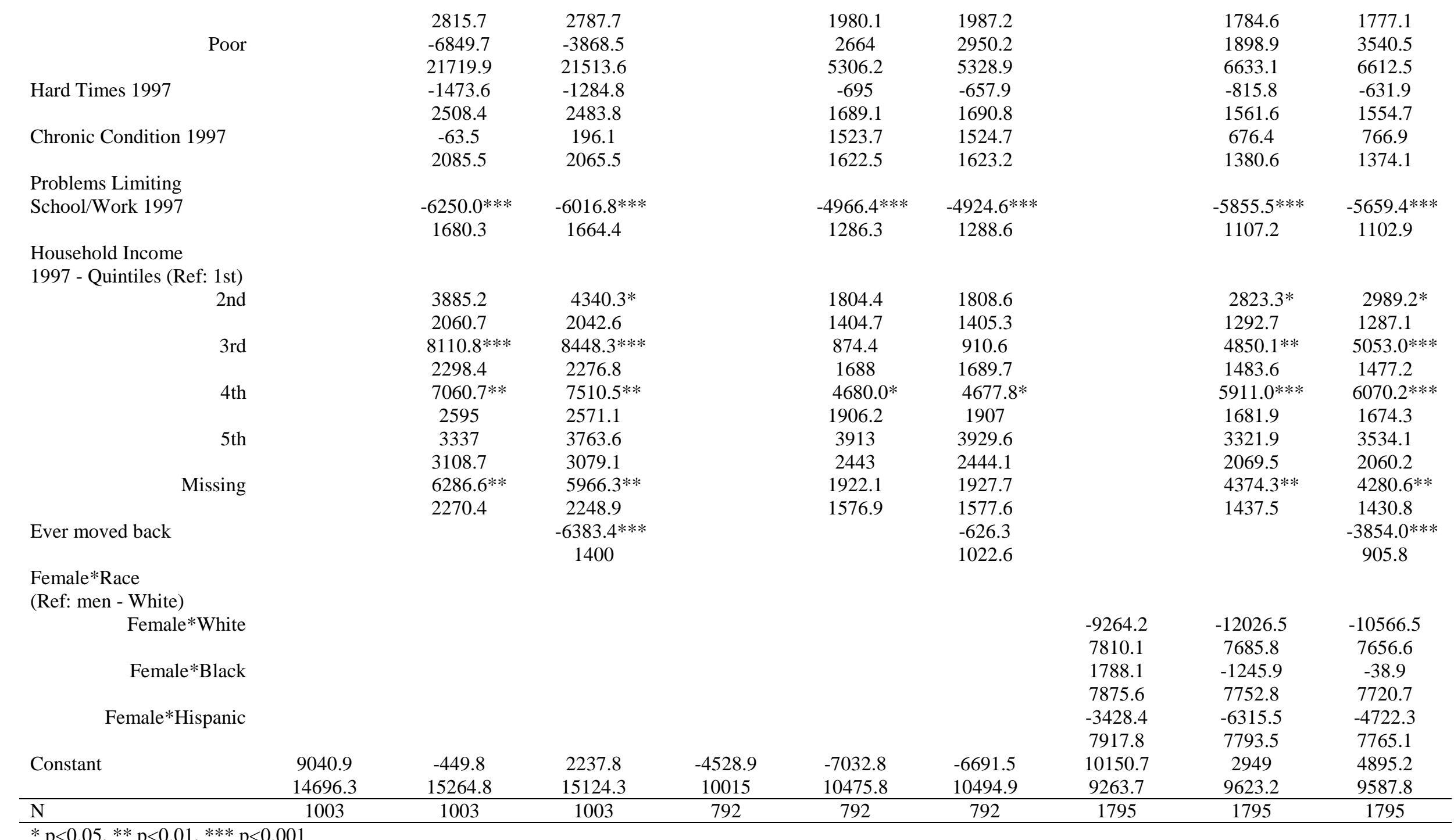


Table A3. Age, Pathways and Income - Ever enrolled in College, by gender + interaction gender*race

\begin{tabular}{|c|c|c|c|c|c|}
\hline & & & Men & & \\
\hline $\begin{array}{l}Y=\text { Work Income } \\
\text { (USD) in } 2010\end{array}$ & (1) & (2) & (3) & (4) & $(5)$ \\
\hline $\begin{array}{l}\text { Age at leaving home } \\
\text { (Ref: 18) }\end{array}$ & & & & & \\
\hline$\leq 17$ & $-6866.8^{*}$ & -3400 & 1109.3 & 2216.2 & 2189.6 \\
\hline & 3117.3 & 3095.8 & 3188.4 & 3182.8 & 3175.9 \\
\hline $19-20$ & $-4104.6^{*}$ & -2560.3 & -3384.7 & -3674.7 & -3300.1 \\
\hline & 2056.4 & 2032.6 & 2331.7 & 2320.9 & 2319.5 \\
\hline $21-22$ & -1513.1 & -213.4 & -2481.6 & -2955.2 & -2586.3 \\
\hline & 2382.3 & 2366.6 & 2956.7 & 2943.8 & 2940.1 \\
\hline$\geq 23$ & -3233.4 & -2640.4 & -5541.1 & -6176.2 & $-6250.1^{*}$ \\
\hline & 2380.3 & 2358.6 & 3177.7 & 3165 & 3158.2 \\
\hline Race (Ref: White) & & & & & \\
\hline Black & $-14897.4 * * *$ & $-9470.2 * * *$ & $-9187.4 * * *$ & $-8989.5 * * *$ & $-8506.4 * * *$ \\
\hline & 1971.8 & 2132.9 & 2112.3 & 2102.1 & 2104.1 \\
\hline Hispanic & $-5656.4 * *$ & -1502.2 & -1155.9 & -1057.8 & -735.4 \\
\hline & 2175.9 & 2310.9 & 2291.2 & 2279.6 & 2277.4 \\
\hline Other race & -2897.4 & -2270.1 & -1692.2 & -1453.8 & -1578.9 \\
\hline & 4088.4 & 4023.3 & 3985.2 & 3965.3 & 3956.9 \\
\hline Age at interview, 2011 & $4433.3 * * *$ & $4297.1 * * *$ & $4404.2 * * *$ & $4389.1 * * *$ & $4368.4 * * *$ \\
\hline & 553.2 & 547 & 541.9 & 539.1 & 538 \\
\hline $\begin{array}{l}\text { Parents' years of } \\
\text { education }\end{array}$ & & 298 & 119.1 & 126.6 & -2.4 \\
\hline & & 298.4 & 296.8 & 295.2 & 298 \\
\hline $\begin{array}{l}\text { Lived w/ both parents } \\
\text { until } 14\end{array}$ & & $5716.1 * *$ & $4566.7 * *$ & $4960.3 * *$ & $4414.0^{*}$ \\
\hline & & 1778.7 & 1770.4 & 1763.8 & 1770.1 \\
\hline Number of Siblings & & -554.7 & -314 & -380.1 & -381 \\
\hline & & 422.4 & 419.9 & 418.1 & 417.1 \\
\hline $\begin{array}{l}\text { Self Rep Health (Ref: } \\
\text { Excellent) }\end{array}$ & & & & & \\
\hline Very good & & $-4105.3^{*}$ & $-4076.5^{*}$ & $-3929.6^{*}$ & $-3943.3^{*}$ \\
\hline & & 1712.7 & 1698.5 & 1690.2 & 1686.5 \\
\hline Good & & $-6592.0 * *$ & $-6502.1 * *$ & $-6195.5 * *$ & $-6011.6^{* *}$ \\
\hline & & 2254.6 & 2231.6 & 2221.4 & 2217.5 \\
\hline Fair & & $-11984.2^{*}$ & $-11205.6^{*}$ & $-12054.5^{*}$ & $-11523.4^{*}$ \\
\hline & & 5669.1 & 5614.5 & 5589.5 & 5580.4 \\
\hline Poor & & -5130.6 & 377.7 & 600.6 & 2081.2 \\
\hline & & 22489.5 & 22276.4 & 22163.2 & 22120.9 \\
\hline Hard Times 1997 & & $-9116.7 *$ & $-8991.9 *$ & $-8744.6^{*}$ & $-8580.8^{*}$ \\
\hline & & 3796.6 & 3760.7 & 3742.1 & 3734.4 \\
\hline Chronic Condition 1997 & & -4385.3 & -4680.8 & -4658.3 & -4571.3 \\
\hline
\end{tabular}




$$
\begin{array}{llll}
2476.2 & 2451.3 & 2438.8 & 2433.7
\end{array}
$$

Problems Limiting

School/Work 1997

$\begin{array}{cccc}-4721.2 & -3354.4 & -3242.5 & -2506.5 \\ 2433 & 2418.6 & 2406.5 & 2414.7\end{array}$

Household Income 1997

- Quintiles (Ref: 1st)

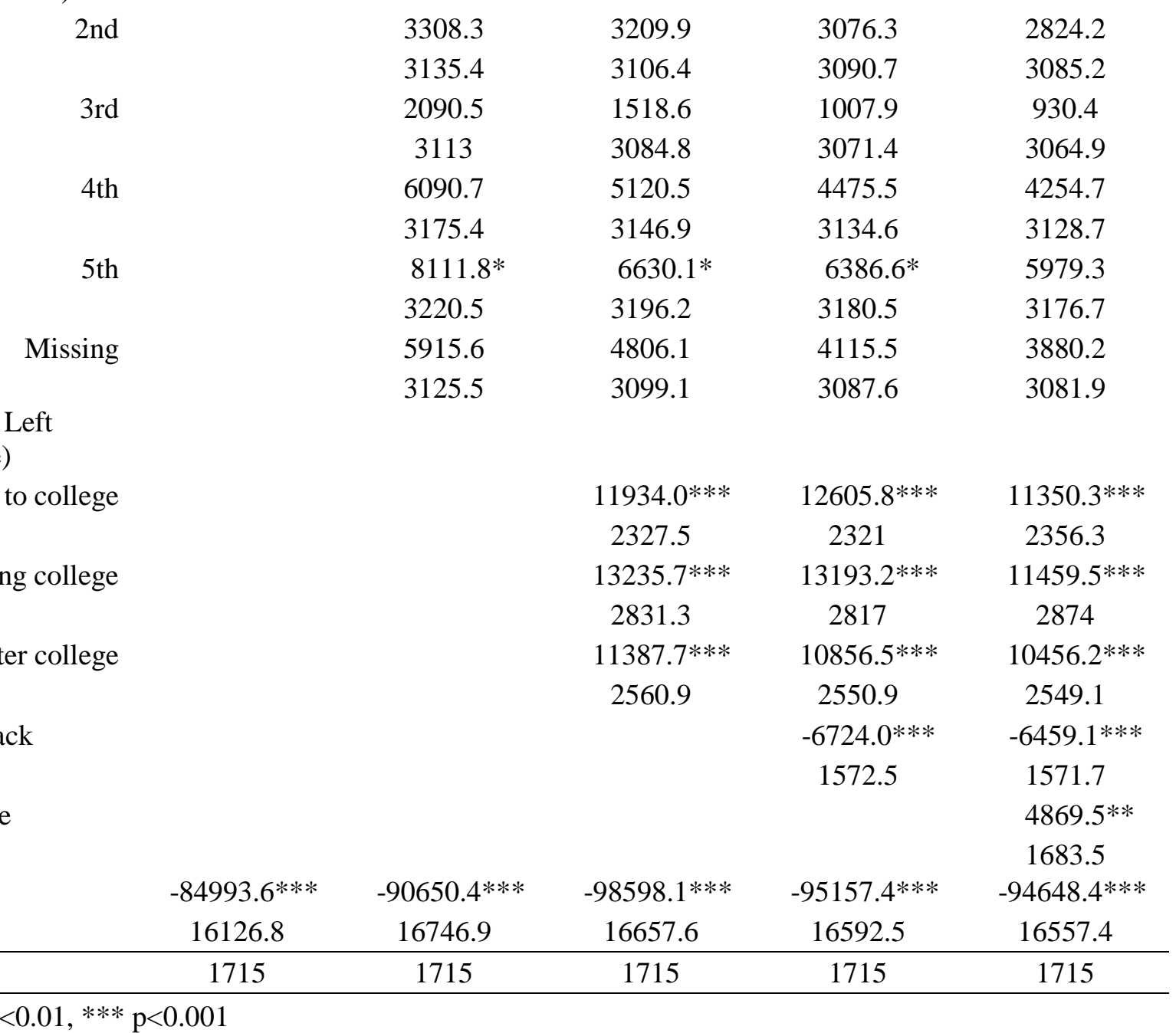

Pathway (Ref: Left

before College)

Left to go to college

Left during college

Left after college

Ever moved back

\section{Women}

Y = Work Income (USD) in 2010

Age at leaving home (Ref:

18)

$\begin{array}{cccccc}\leq 17 & -8060.1 * * * & -4544.9^{*} & -430.8 & -233.1 & -96.7 \\ & 1874.3 & 1854 & 1909 & 1916.4 & 1878.5 \\ 19-20 & -4145.5^{* *} & -2953.6^{*} & -5359.4^{* * *} & -5379.3 * * * & -4348.6^{* *} \\ & 1390 & 1358.1 & 1623.1 & 1623 & 1594.8 \\ 21-22 & -1475.6 & -681.5 & -3552.8 & -3701 & -3083.9\end{array}$

(3)

(2)

(1)
(4)

(5) 


$\begin{array}{llllll} & 1610.3 & 1569.4 & 1985.8 & 1989.7 & 1951.4 \\ \geq 23 & -2735 & -2460.1 & -5228.3^{*} & -5427.8^{*} & -5466.9^{*} \\ & 1810.9 & 1768.3 & 2315.2 & 2321.3 & 2275.3\end{array}$

Race (Ref: White)

$\begin{array}{rccccc}\text { Black } & -7857.5^{* * *} & -2711.2 & -2629.4 & -2598.6 & -2020.2 \\ & 1279.4 & 1389.1 & 1367.8 & 1367.9 & 1342.3 \\ \text { Hispanic } & -4802.7^{* *} & -24.6 & -146.6 & -135.1 & 91.7 \\ & 1511.6 & 1606.1 & 1581.8 & 1581.7 & 1550.5 \\ \text { Other race } & 9849.7 * * * & 9010.8^{* *} & 8952.5^{* *} & 9075.9^{* *} & 8035.9^{* *} \\ & 2936 & 2871.1 & 2821.2 & 2822.9 & 2769.3 \\ 2011 & 1214.4^{* *} & 1220.0^{* * *} & 1338.4^{* * *} & 1361.9 * * * & 1349.3^{* * *} \\ & 376.4 & 366.9 & 360.8 & 361.4 & 354.2 \\ \text { education } & & 627.2^{* *} & 401.0^{*} & 389.4 & 88.4 \\ & & 203.9 & 202.1 & 202.4 & 201\end{array}$

Lived w/ both parents until 14

$\begin{array}{cccc}3973.7 * * * & 2968.3 * & 2991.0^{*} & 2350.8^{*} \\ 1179.4 & 1168.2 & 1168.3 & 1147.2 \\ -316.5 & -222.2 & -230.6 & -211.5 \\ 249.1 & 245.1 & 245.1 & 240.3\end{array}$

Self Rep Health (Ref:

Excellent)

Very good
Good
Fair
Poor

Hard Times 1997

Chronic Condition 1997

Problems Limiting

School/Work 1997

Household Income 1997 Quintiles (Ref: 1st)

$$
-185
$$

1215.3

$-1513.5$

$-1424$

$-1664.7$

$-3385.6^{*}$

1195.1

1437.4

$-2886.3^{*}$

1197.5

1174

$-6911.0 * *$

1413.6

2653.2

$-5136.2 *$

2615.6

$-13251$

13776.2

$-10289.5$

$-407.5$

2597.1

1170.7

1768.8

13541.6

$-2875.4 *$

$-2442.7$

1413.5

1386.2

$-5168.5^{*}$

$-5677.7 *$

2615.5

2564.2

$-9711.3$

$-12350.6$

13549.6

13284

602.5

2556

1185.3

1913.8

2556.3

1138

1739.2

2509.4

1738.9

882.4

1705

$-6682.1 * *$

2042.3
$-6057.7^{* *}$

2008.2
$-6035.3 * *$

2008.1
$-4836.6^{*}$

1972.6 2nd

3rd

4th

$\begin{array}{ll}3319.2 & 2527.4 \\ 2034.2 & 2004.4 \\ 2792.5 & 1422.4 \\ 2016.6 & 1988.3 \\ 5080.1^{*} & 3456.3\end{array}$

2539.4
2004.2
1416.6
1988.1
3552.2

2286.5

1964.7

1219

1948.8

3005.7 


\begin{tabular}{rcccc} 
& 2051.1 & 2026.3 & 2027.8 & 1988.5 \\
\multirow{3}{*}{5 th } & $11179.6^{* * *}$ & $9607.3^{* * *}$ & $9643.8^{* * * *}$ & $8900.6^{* * *}$ \\
& 2133.2 & 2104.4 & 2104.5 & 2064.3 \\
\multirow{2}{*}{ Missing } & $4452.3^{*}$ & 2898.4 & 2938.8 & 2383.6 \\
& 2000.1 & 1973.5 & 1973.6 & 1935.4
\end{tabular}

Pathway (Ref: Left before College)

Left to go to college

$\begin{array}{ccc}10308.7 * * * & 10414.0^{* * *} & 6821.7 * * * \\ 1606.6 & 1609 & 1624.8\end{array}$

Left during college

$14938.0 * * *$

$14881.3^{* * *}$

$11574.6^{* * * *}$

Left after college

1879.5

1880

1877.5

$10134.8^{* * *}$

$10063.3 * * *$

$8740.3 * * *$

1831.7

1832.5

1802

Ever moved back

$-1245.9 \quad-598.7$

$1072.5 \quad 1053.6$

College Degree

$10613.7^{* * *}$

1154.3

\begin{tabular}{lccccc} 
Constant & -3307.2 & -19207.4 & $-25818.1^{*}$ & $-25868.4^{*}$ & $-26116.9 *$ \\
& 11021.8 & 11343.9 & 11178.2 & 11177.3 & 10955.7 \\
\hline $\mathrm{N}$ & 2072 & 2072 & 2072 & 2072 & 2072 \\
\hline
\end{tabular}

$* \mathrm{p}<0.05, * * \mathrm{p}<0.01, * * * \mathrm{p}<0.001$

Table A3 Cont.

\begin{tabular}{|c|c|c|c|c|c|}
\hline \multirow{2}{*}{$\begin{array}{l}\text { Y = Work Income } \\
\text { (USD) in } 2010\end{array}$} & \multicolumn{5}{|c|}{ Interaction Gender*Race } \\
\hline & (1) & (2) & (3) & (4) & $(5)$ \\
\hline \multicolumn{6}{|l|}{$\begin{array}{l}\text { Age at leaving home } \\
\text { (Ref: 18) }\end{array}$} \\
\hline \multirow{2}{*}{$\leq 17$} & $-7633.2 * * *$ & $-4107.2 *$ & 70.9 & 714.4 & 761.8 \\
\hline & 1701.6 & 1685.4 & 1737.1 & 1739.6 & 1725.4 \\
\hline \multirow[t]{2}{*}{$19-20$} & $-4250.5^{* * *}$ & $-2808.2 *$ & $-4563.8 * * *$ & $-4676.5^{* * *}$ & $-3984.9 * *$ \\
\hline & 1201.9 & 1180.7 & 1384.4 & 1381.4 & 1373 \\
\hline \multirow[t]{2}{*}{$21-22$} & -1418.8 & -306.7 & -3023 & $-3409.7 *$ & -2915.2 \\
\hline & 1392.6 & 1367 & 1721.9 & 1720.3 & 1707.5 \\
\hline \multirow[t]{2}{*}{$\geq 23$} & $-2939.5^{*}$ & -2520.3 & $-5546.2 * *$ & $-6042.2 * *$ & $-6140.5 * *$ \\
\hline & 1476.2 & 1450.4 & 1930.6 & 1929.6 & 1914 \\
\hline \multirow[t]{2}{*}{ Female } & 119.7 & 31.6 & -1307.9 & -1148.3 & -2227.6 \\
\hline & 4785.2 & 4681.8 & 4625.1 & 4614.6 & 4579.1 \\
\hline \multicolumn{6}{|l|}{ Race (Ref: White) } \\
\hline \multirow[t]{2}{*}{ Black } & $-14624.6^{* * *}$ & $-9405.6 * * *$ & $-9187.0 * * *$ & $-9084.9 * * *$ & $-8303.4 * * *$ \\
\hline & 1720.5 & 1762.6 & 1740 & 1736.2 & 1724.9 \\
\hline \multirow[t]{2}{*}{ Hispanic } & $-5298.3 * *$ & -860.8 & -637 & -610.1 & -162.8 \\
\hline & 1899.6 & 1926.2 & 1902.7 & 1898.3 & 1883.7 \\
\hline
\end{tabular}




\begin{tabular}{|c|c|c|c|c|c|}
\hline Other race & $\begin{array}{l}-2611.1 \\
3580.7\end{array}$ & $\begin{array}{l}-2211.3 \\
3504\end{array}$ & $\begin{array}{c}-1610.6 \\
3459.8\end{array}$ & $\begin{array}{c}-1450.1 \\
3452\end{array}$ & $\begin{array}{c}-1624.4 \\
3424\end{array}$ \\
\hline $\begin{array}{l}\text { Age at interview, } \\
2011\end{array}$ & $\begin{array}{l}2658.9 * * * \\
324.5\end{array}$ & $\begin{array}{l}2619.2^{* * * *} \\
318.3\end{array}$ & $\begin{array}{l}2732.8^{* * *} \\
314.4\end{array}$ & $\begin{array}{l}2769.9 * * * \\
313.8\end{array}$ & $\begin{array}{l}2751.3^{* * *} \\
311.3\end{array}$ \\
\hline $\begin{array}{l}\text { Parents' years of } \\
\text { education }\end{array}$ & & $\begin{array}{l}485.9^{* *} \\
175.3\end{array}$ & $\begin{array}{l}283.2 \\
174.2\end{array}$ & $\begin{array}{c}265 \\
173.8\end{array}$ & $\begin{array}{c}45.3 \\
174.6\end{array}$ \\
\hline $\begin{array}{l}\text { Lived w/ both parents } \\
\text { until } 14\end{array}$ & & $\begin{array}{l}4680.1 * * * \\
1027.6\end{array}$ & $\begin{array}{l}3629.7 * * * \\
1021\end{array}$ & $\begin{array}{l}3769.6^{* * *} \\
1019.2\end{array}$ & $\begin{array}{l}3122.8^{* *} \\
1014.2\end{array}$ \\
\hline Number of Siblings & & $\begin{array}{l}-405.2 \\
228\end{array}$ & $\begin{array}{l}-257 \\
225.6\end{array}$ & $\begin{array}{c}-287.6 \\
225.1\end{array}$ & $\begin{array}{l}-280.1 \\
223.3\end{array}$ \\
\hline $\begin{array}{l}\text { Self Rep Health (Ref: } \\
\text { Excellent) }\end{array}$ & & & & & \\
\hline Very good & & $\begin{array}{l}-3138.0^{* *} \\
1026.1\end{array}$ & $\begin{array}{l}-2910.5^{* *} \\
1013.5\end{array}$ & $\begin{array}{l}-2710.1^{* *} \\
1012.3\end{array}$ & $\begin{array}{l}-2803.9^{* *} \\
1004.1\end{array}$ \\
\hline Good & & $\begin{array}{l}-4897.5^{* * *} \\
1271.4\end{array}$ & $\begin{array}{l}-4588.3 * * * \\
1255.4\end{array}$ & $\begin{array}{l}-4494.7 * * * \\
1252.7\end{array}$ & $\begin{array}{l}-4180.6^{* * *} \\
1243.2\end{array}$ \\
\hline Fair & & $\begin{array}{l}-8537.9^{* *} \\
2606.2\end{array}$ & $\begin{array}{l}-7108.1 * * \\
2577.6\end{array}$ & $\begin{array}{l}-7318.7 * * \\
2572.2\end{array}$ & $\begin{array}{l}-7367.1^{* *} \\
2551.3\end{array}$ \\
\hline Poor & & $\begin{array}{l}-8392.2 \\
12419.8\end{array}$ & $\begin{array}{l}-4477.4 \\
12265.8\end{array}$ & $\begin{array}{l}-3372.5 \\
12240.3\end{array}$ & $\begin{array}{l}-3646.9 \\
12140.9\end{array}$ \\
\hline Hard Times 1997 & & $\begin{array}{l}-4643.9^{*} \\
2230.4\end{array}$ & $\begin{array}{l}-4045.7 \\
2202.6\end{array}$ & $\begin{array}{c}-3965.4 \\
2197.6\end{array}$ & $\begin{array}{l}-3299.4 \\
2181.4\end{array}$ \\
\hline $\begin{array}{l}\text { Chronic Condition } \\
1997\end{array}$ & & $\begin{array}{c}-1567.8 \\
1489.5\end{array}$ & $\begin{array}{r}-1753.2 \\
1470.4\end{array}$ & $\begin{array}{c}-1657.4 \\
1467.2\end{array}$ & $\begin{array}{c}-1725.4 \\
1455.3\end{array}$ \\
\hline $\begin{array}{l}\text { Problems Limiting } \\
\text { School/Work } 1997\end{array}$ & & $\begin{array}{l}-5642.9 * * * \\
1581.7\end{array}$ & $\begin{array}{l}-4619.9 * * \\
1564.6\end{array}$ & $\begin{array}{l}-4540.0 * * \\
1561.1\end{array}$ & $\begin{array}{l}-3492.7 * \\
1554.1\end{array}$ \\
\hline $\begin{array}{l}\text { Household Income } \\
1997 \text { - Quintiles (Ref: } \\
\text { 1st) }\end{array}$ & & & & & \\
\hline 2nd & & $\begin{array}{l}3398 \\
1791\end{array}$ & $\begin{array}{l}2925.3 \\
1770.7\end{array}$ & $\begin{array}{c}2918 \\
1766.6\end{array}$ & $\begin{array}{l}2652.8 \\
1752.6\end{array}$ \\
\hline $3 \mathrm{rd}$ & & $\begin{array}{l}2659.5 \\
1775.6\end{array}$ & $\begin{array}{l}1661.7 \\
1756.2\end{array}$ & $\begin{array}{l}1516.2 \\
1752.5\end{array}$ & $\begin{array}{l}1380.7 \\
1738.3\end{array}$ \\
\hline 4 th & & $\begin{array}{l}5892.5^{* *} \\
1808.9\end{array}$ & $\begin{array}{l}4553.2^{*} \\
1791.2\end{array}$ & $\begin{array}{l}4560.0^{*} \\
1787.1\end{array}$ & $\begin{array}{l}4162.9^{*} \\
1773.3\end{array}$ \\
\hline 5 th & & $\begin{array}{l}9822.1 * * * \\
1859.9\end{array}$ & $\begin{array}{l}8285.8^{* * * *} \\
1842.3\end{array}$ & $\begin{array}{l}8308.3^{* * * *} \\
1838.1\end{array}$ & $\begin{array}{l}7708.6 * * * \\
1824.7\end{array}$ \\
\hline Missing & & $\begin{array}{l}5318.6^{* *} \\
1771.3\end{array}$ & $\begin{array}{l}3969.0^{*} \\
1753.6\end{array}$ & $\begin{array}{l}3869.1 * \\
1749.7\end{array}$ & $\begin{array}{l}3477.7 * \\
1736.2\end{array}$ \\
\hline $\begin{array}{l}\text { Pathway (Ref: Left } \\
\text { before College) }\end{array}$ & & & & & \\
\hline Left to go to college & & & $10786.6^{* * *}$ & $11158.7 * * *$ & $8771.9 * * *$ \\
\hline
\end{tabular}


Left during college

Left after college

Ever moved back

College Degree

Female*Race (Ref:

men - White)

\begin{tabular}{|c|c|c|c|c|c|}
\hline \multirow[t]{2}{*}{ Female*White } & $-12718.0^{*}$ & $-11954.8^{*}$ & $-11327.1 *$ & $-11512.8^{*}$ & $-10943.4 *$ \\
\hline & 4941.7 & 4833 & 4771.3 & 4760.5 & 4722.4 \\
\hline \multirow[t]{2}{*}{ Female*Black } & -5890.7 & -5136.3 & -4594.2 & -4779.7 & -4562 \\
\hline & 5144.8 & 5036.3 & 4973.1 & 4961.8 & 4921.6 \\
\hline \multirow[t]{2}{*}{ Female*Hispanic } & $-12101.1^{*}$ & $-11413.0^{*}$ & $-11093.1^{*}$ & $-11243.6^{*}$ & $-10914.6^{*}$ \\
\hline & 5292.8 & 5177.1 & 5110.9 & 5099.3 & 5058 \\
\hline \multirow[t]{2}{*}{ Constant } & $-33107.1 * * *$ & $-45423.3^{* * *}$ & $-52088.2 * * *$ & $-51266.2 * * *$ & $-50736.2 * * *$ \\
\hline & 9480.6 & 9801.7 & 9710.3 & 9689.8 & 9611.3 \\
\hline $\mathrm{N}$ & 3787 & 3787 & 3787 & 3787 & 3787 \\
\hline
\end{tabular}

$\begin{array}{ccc}1377 & 1376.6 & 1398.2 \\ 14156.6^{* * *} & 14051.8^{* * *} & 11478.7^{* * *} \\ 1634.3 & 1630.7 & 1649.7 \\ 10664.1^{* * *} & 10399.7 * * * & 9590.0^{* * *} \\ 1543 & 1540.7 & 1531.6 \\ & -3952.8^{* * *} & -3510.6^{* * *} \\ & 922.6 & 916.8 \\ & & 7886.7^{* * *} \\ & & 995.6\end{array}$

Ever moved back

(n)

